\title{
بعض التغيرات المورفولوجية المعاصرة \\ للساحل الشمالى لسيناء شرق

$$
\text { بحيرة البردويل }
$$

$$
\begin{aligned}
& \text { دكتور/عادل عبدالمنعم أحمد السعدنى } \\
& \text { أستاذ الجيومورفولوجيا المساعد } \\
& \text { بكلية الآداب - جامعة قناة السويس }
\end{aligned}
$$


- $Y=$ 
تتمتع شبه جزيرة سيناء بموقع جغرافى متميز، فهى محاطة بمسطحات مائية من ثلاث

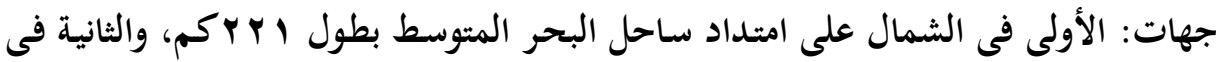

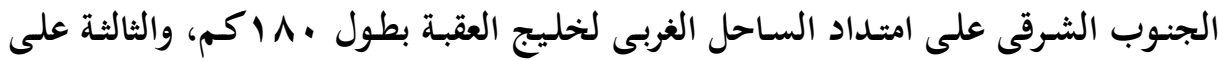
امتداد الساحل الشرقى لخليج السويس بطول ه ه كـم، هذا الموقع جعلها محل أنظار واهتمام الجميع مع التركيز على بعض الأخطار الطبيعية التى تتعرض لها وكيفية التغلب عليها، وترويضها لخدمة الإنسان، من هنا أتت فكرة البحث فى التركيز على التغيرات المورفولوجية

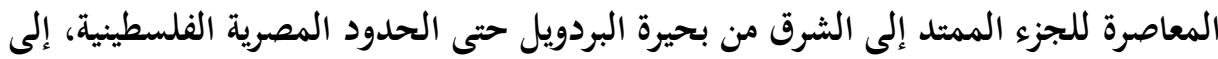
الجنوب من البحر المتوسط حتى خط كنتور • ع م فوق مستوى سطح البحر، حيث لوحظ فى الفترات الحديثة تعرض هذه المنطقة إلى العديد من التغيرات المورفولوجية، التى أثرت

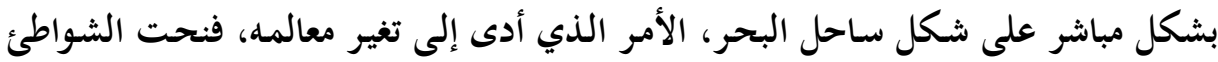

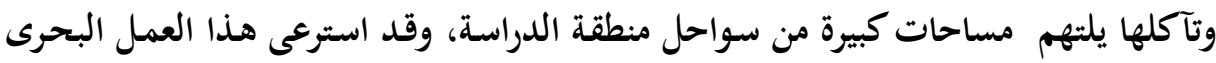

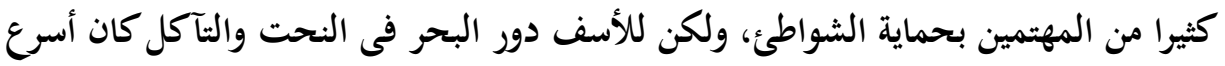
من المهتمين بهذه القضية بسبب عمله ليل نهار، مما أدى إلى عدم صمود وسائل الحماية طويلاً، علاوة على أن الإنسان لم يستخدم الوسائل الحديثة فى حماية الشواطئ، مما أدى لهي

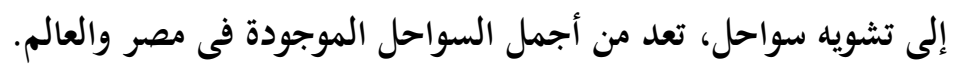

يقصــد بـالتغيرات المورفولوجيـة المعاصـرة للســاحل الشـمالى لسـيناء شـرق بحيــة

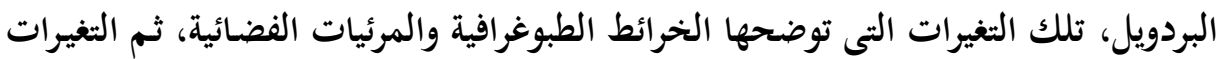
التى حدثت بسبب المنشآت التى أقيمت على امتداد الساحل، وذلك من خحلال الدراسة الميدانية.

وتهدف الدراسة إلى التعرف على أهم الخصائص الجيومورفولوجية الحديثة للساحل

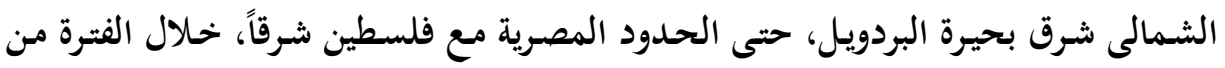

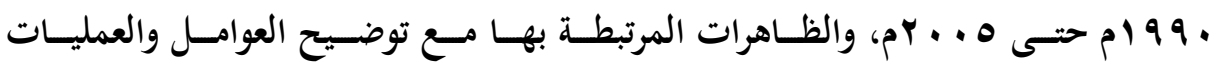
المورفولوجية المؤثرة فيها، إلى جانب دور الإنسان فى تغيير وتشكيل الساحل. 
تنطلب مشكلة نحت وتآكل الساحل تضافر عديد من الجهود العلمية والعملية،

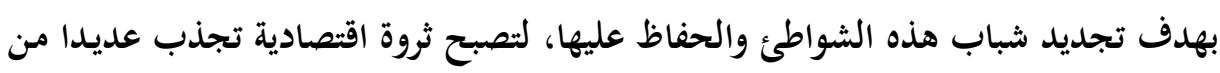

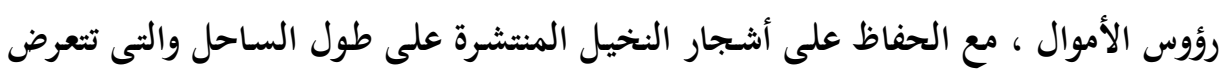

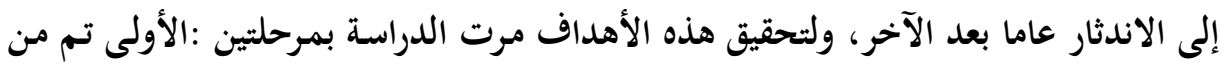

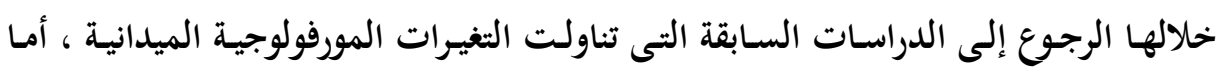

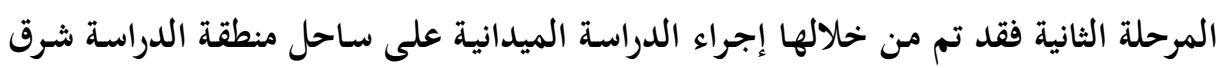

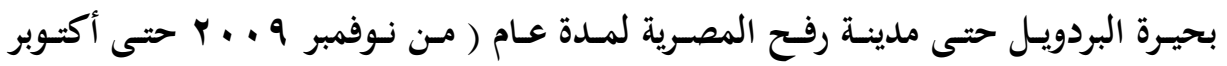

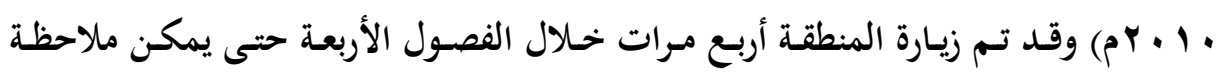

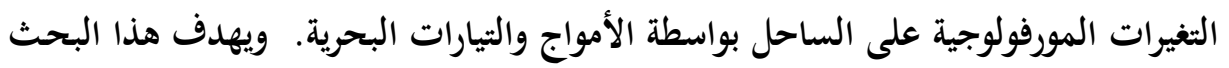

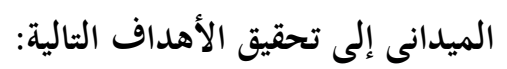

أولاً: الخصائص الجيولوجية لمنطقة الدراسة.

تؤثر خصائص رواسب السطح بمنطقة الدراسة على مدلى نشاط عمليات النحت

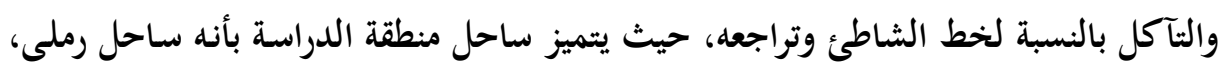

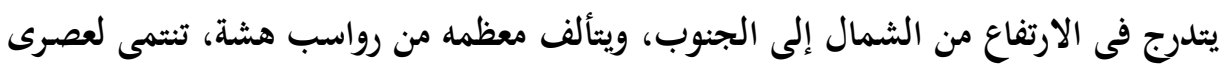

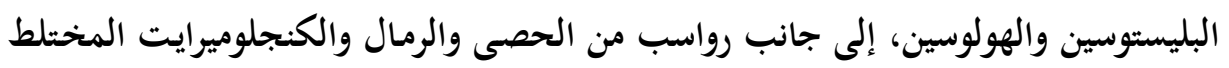

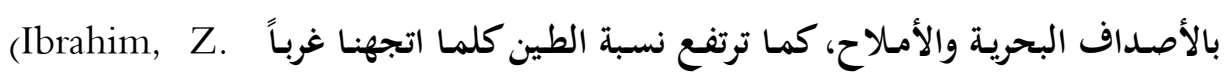

(1) شكل Elshamy, 1995, P.173) 


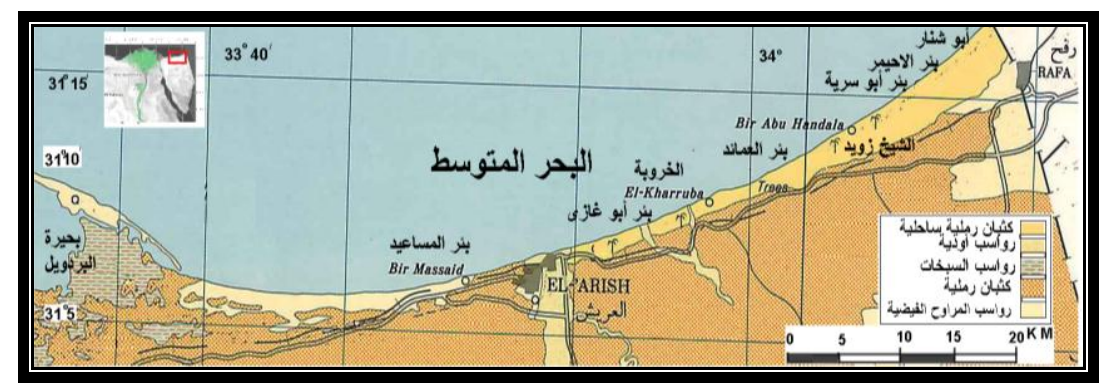

شكل(1) الخريطة الجيولوجية لمنطقة الدراسة

المصدر: الخريطة الجيولوجية لسيناء لوحة رقم | مقياس \: ... . .

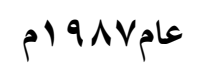

إلى جانب انتشار رواسب السبخات فى أجزاء متفرقة كما فى محطة الميدان والمزار

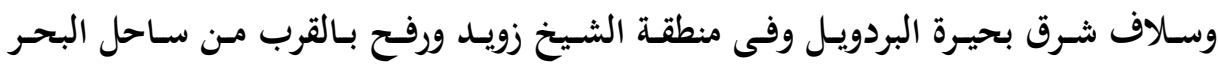

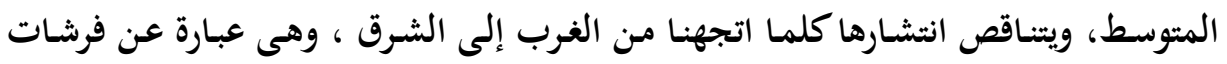

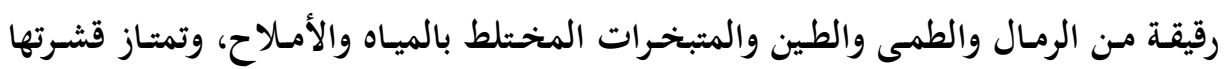

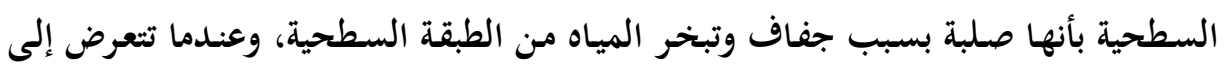
سقوط الأمطار أو امتداد مياه البحر فإنها تتحول إلى تربة لزجة، يصعب بسب السير فوقها. تنتشر فى المنطقة كذلك رواسب الأودية والفرشات الرملية، الأولى فوق سطح دلتا

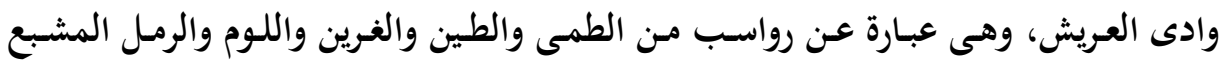

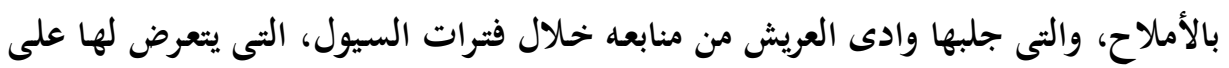

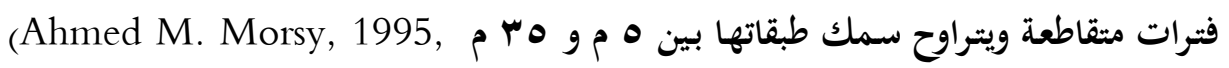

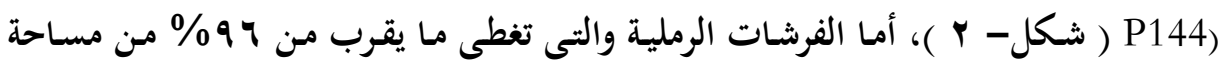

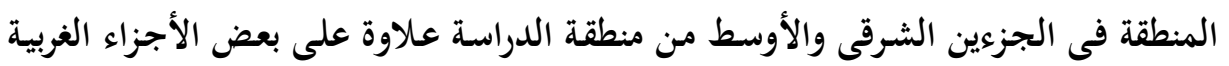

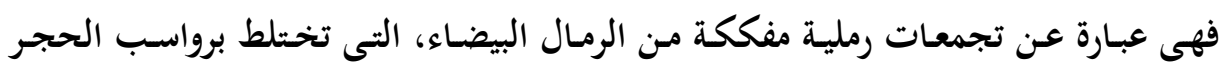

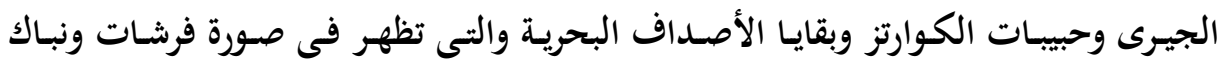

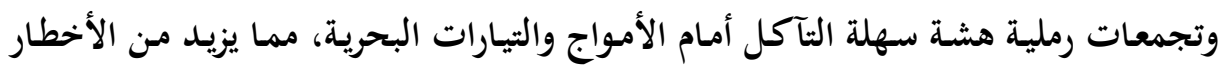
الجيومورفولوجية التى تهدد ساحل منطقة الدراسة. 


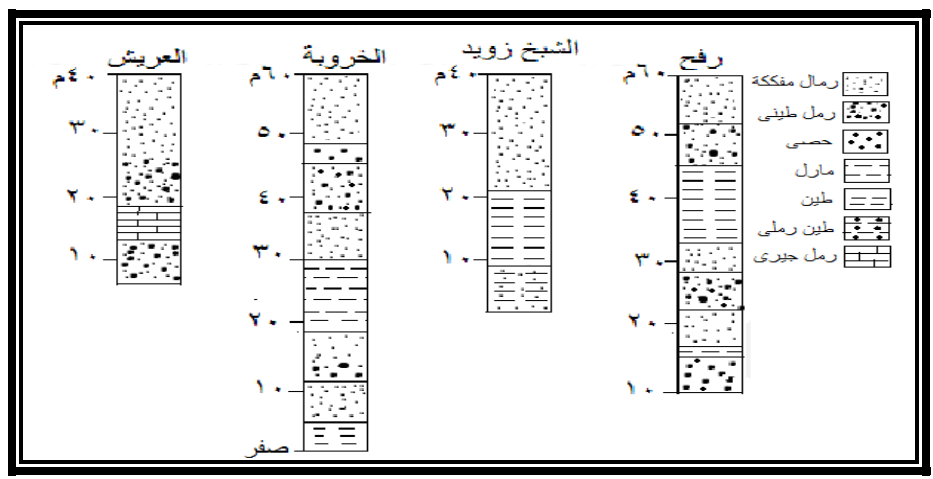

شكل (ץ) قطاعات جيولوجية رأسية لمنطقة الدراسة.

المصدر: (Ahmed M, Omar A., and Mohamed I. Ismail ,1995,p145)

\section{ثانياً: الخصائص المناخية.}

تـرتبط بعناصـر المنـاخ بعض العمليـات الجيومورفولوجيـة، فهنـاك علاقـة طرديـة بـين

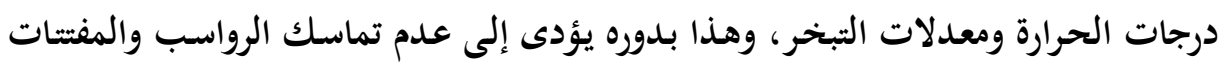
الصخرية، كما تمتاز منطقة الدراسة بتفاوت درجات الحرارة ما بين الصيف والشتاء والليل واليل

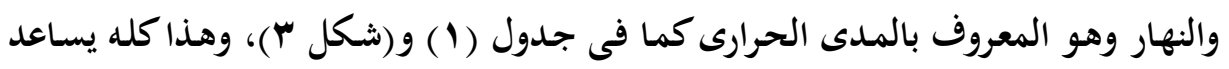
على نشاط عمليات التجوية بمنطقة الدراسة.

تؤثر درجات الحرارة كذلك على معدل تسرب المياه من خحلال مسام التربة، حيث

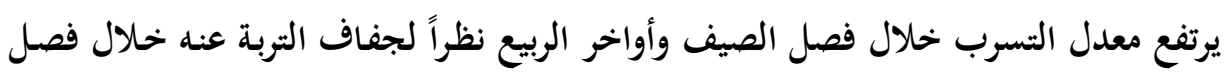

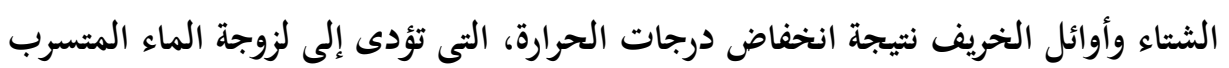

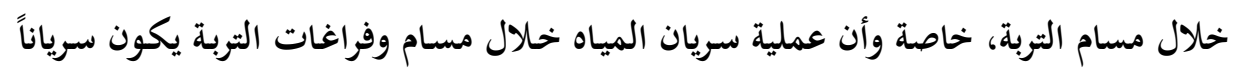

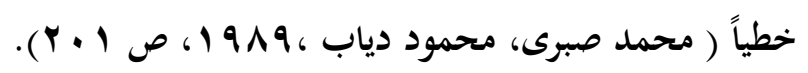



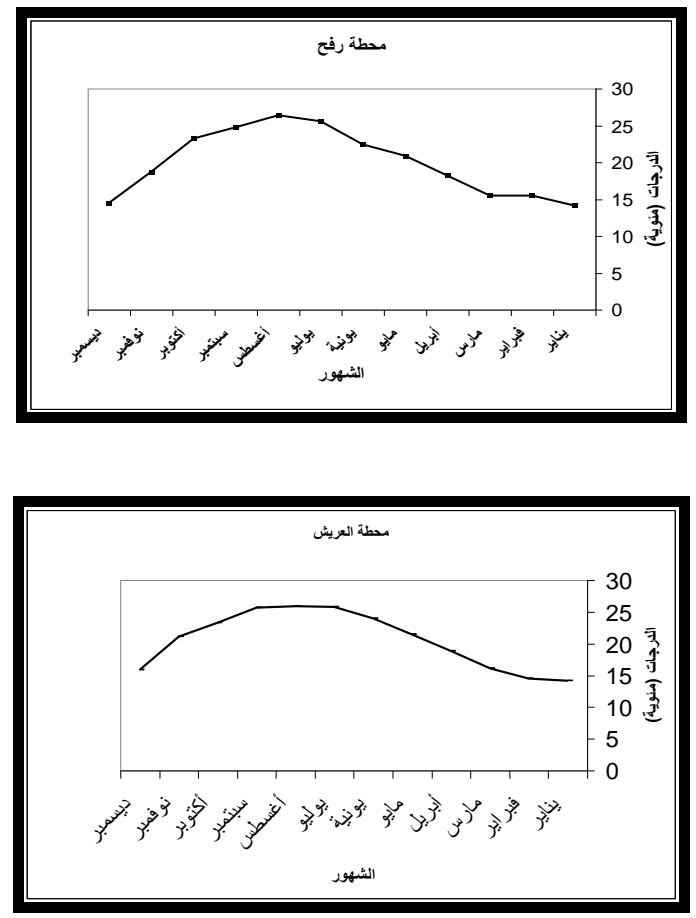

شكل (ب) درجات الحرارة بمنطقة الدراسة

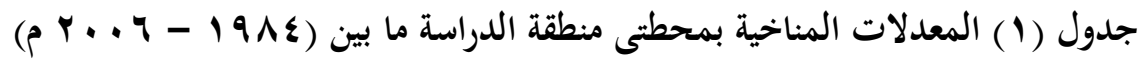

\begin{tabular}{|c|c|c|c|c|c|c|c|c|}
\hline \multicolumn{4}{|c|}{ رفح } & \multicolumn{4}{|c|}{ العريش } & \multirow[b]{2}{*}{ الشهر } \\
\hline $\begin{array}{l}\text { الرطوبة } \\
\text { (\%) }\end{array}$ & سرعة الرياح & مم & $\begin{array}{c}\text { الحرارة) } \\
\text { ا(م) }\end{array}$ & $\begin{array}{c}\text { الرطوبة } \\
\text { (\%) }\end{array}$ & سرعة الرياح & (مم) & $\begin{array}{c}\text { الحرارة } \\
\text { ا(ج) }\end{array}$ & \\
\hline VI & $0 . Y$ & r. & $1 \leq .1$ & vi & $\varepsilon .9$ & $r \cdot r$ & IE.Y & يناير \\
\hline vi & $v .9$ & YV.Y & 10.0 & vi & 0.1 & 11.0 & $1 \leq .0$ & فبراير \\
\hline 79 & $\wedge$ & $1 \leq . Y$ & 10.0 & IV & 0.9 & 17.9 & 17.1 & مارس \\
\hline 79 & $v$ & .1 & IN.r & $7 V$ & $\varepsilon .9$ & V.1- & $1 \wedge .1$ & أبريل \\
\hline או & $\wedge$ & $\varepsilon .0$ & $r \cdot q q$ & 79 & $\varepsilon . \Lambda$ & $\varepsilon .1-$ & ri.0 & مايو \\
\hline$V \varepsilon$ & $v$ & صفر & YY.E & IV & $\leq .0$ & صفر & rr.q & يونيو \\
\hline vo & $v$ & صفر & Y0.7 & vo & $\varepsilon . \varepsilon$ & صفر & YO.A & يوليو \\
\hline
\end{tabular}




\begin{tabular}{|c|c|c|c|c|c|c|c|c|}
\hline \multicolumn{4}{|c|}{ رفح } & \multicolumn{4}{|c|}{ العريش } & \multirow[b]{2}{*}{ الشهر } \\
\hline $\begin{array}{l}\text { الرطوبة\%) } \\
\text { (\%) }\end{array}$ & (عقدة الرياح & مم المطر & الحُرارة & $\begin{array}{l}\text { الرطوبة\% } \\
\text { (\%) }\end{array}$ & سرعة الرياح & (مم) & الحرارة & \\
\hline vo & V.r & صفر & ץ..ร & vo & $\varepsilon . r$ & •r & Yo.q & أغسطس \\
\hline$V \varepsilon$ & V.1 & صفر & $r \leqslant . \Lambda$ & VY & $\varepsilon . Y$ & $\cdot \varepsilon$ & Yo.v & سبتمبر \\
\hline$V \varepsilon$ & 0.1 & $r$. & rT.Y & Vr & r.A & 7. & rT.r & أكتوبر \\
\hline vo & r.r & $9 \leqslant .0$ & IN.V & Vr & $\varepsilon . r$ & 17.1 & Y.1 & نوفمبر \\
\hline v. & r.乏 & 9. & $1 \leqslant .0$ & 79 & $\varepsilon . \wedge$ & Y $\leqslant . \varepsilon$ & 10.9 & ديسمبر \\
\hline VY.I & ד. & rr & $r \cdot . \cdot$ & $v \cdot . \varepsilon$ & $\varepsilon . V$ & 11.1 & $r \cdot . \varepsilon$ & المتوسط \\
\hline
\end{tabular}

المصدر: الهيئة العامة للأرصاد الجوية بالقاهرة.

تتباين اتجاهات وسرعة الرياح على ساحل منطقة الدراسة من فصل لأخر جدول (Y)،

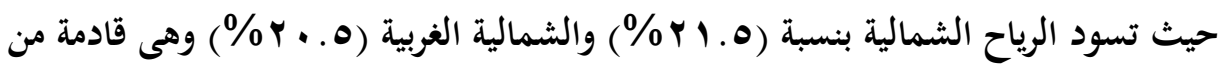
فوق البحر المتوسط، أى أنها تصطدم بمياه البحر قبل الوصول إلى شاطئ منطقة الدراسة،

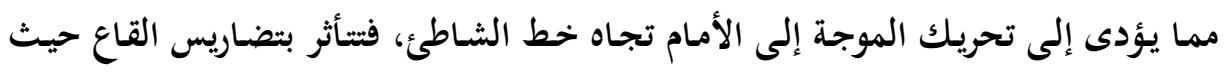
تتناقص أطوالها وسرعتها بشكل واضح وعندما تتكسر الأمواج عند اقترابها من الشاطئ فئل إِان

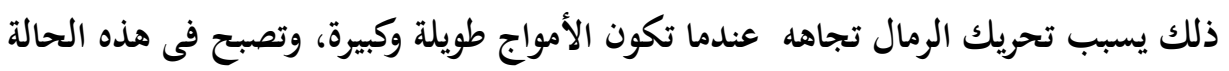

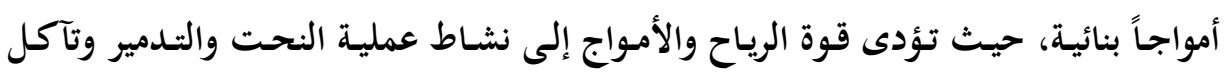

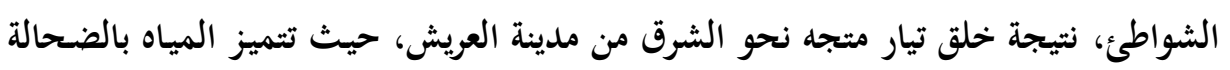
وقصر الأمواج.

يلاحظ من (الثكل \& ) والجدول (Y) أن الرياح السائدة هى رياح شمالية

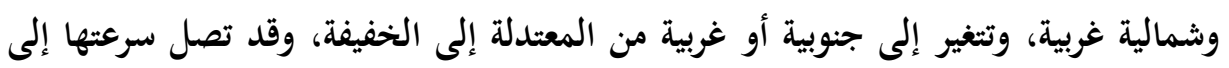

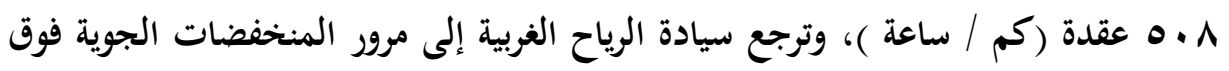

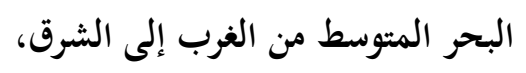




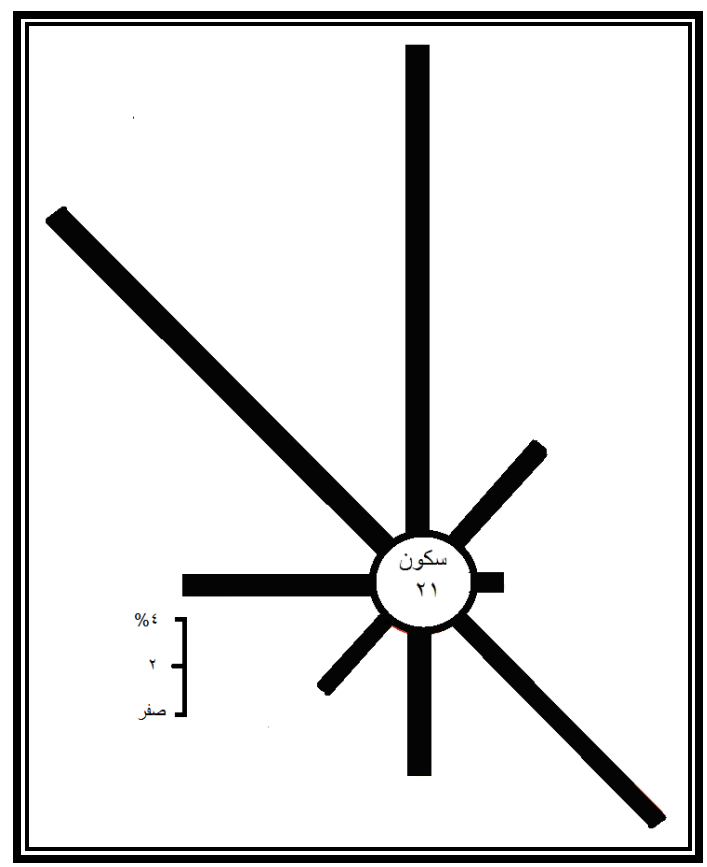

شكل ( ع ) اتجاهات الرياح بمنطقة الدراسة

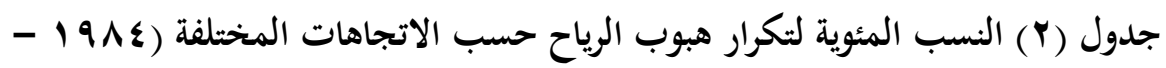
$\cdot($ r. +4

\begin{tabular}{|c|c|c|c|c|c|c|c|c|c|c|}
\hline الفصل & سكون & شرب & غرب & غرب & جنوب & شنوب & شرق & شمال & شمال & \\
\hline الشتاء & ro.r & r. & $1 . .5$ & rI.r & $1 . .7$ & $0 . v$ & $1 . \varepsilon$ & $0 . r$ & 1. & \multirow{4}{*}{ العريش } \\
\hline الربيع & $r 1.1$ & Y. & T.Y & ^..- & $\varepsilon . \Gamma$ & $\varepsilon .0$ & 1.0 & $9 .+-$ & $r \varepsilon$ & \\
\hline الصيف & rV.o & Yr..- & V.. - & 9..- & Y. 0 & 1.0 & .0 & r..- & Y & \\
\hline \multirow[t]{2}{*}{ الخريف } & YY.V & Y $\varepsilon$. & $\varepsilon . Y$ & 9.0 & ๑.. & $\varepsilon$. & $\cdot 0$ & ๑..- & ro & \\
\hline & $r \leq . r T$ & 19.8 & 7.9 & 11.1 & 0.7 & $r .9$ & - .9V- & 0.7 & r..r & المتوسط \\
\hline الشتاء & 17.1 & 11.9 & 11.7 & $r \leqslant .0$ & Ir.r & $0 . r$ & r.r & 0.1 & $11 .$. & \\
\hline الربيع & $1 \leqslant .9$ & r.r.r & A.1 & 1.9 & $\varepsilon . V$ & 0.7 & 1.9 & 9.1 & $r \leq .1$ & رفح \\
\hline
\end{tabular}




\begin{tabular}{|c|c|c|c|c|c|c|c|c|c|c|}
\hline الفصل & سكون & شرب & غرب & غنوب & جنوب & شنوب & شرق & شمال & شمال & \\
\hline الصيف & YY.. & Yr.Y & 1.1 & 9.7 & r. 9 & 1.V & $1 . .-$ & $r . r$ & Y O. & \\
\hline \multirow[t]{2}{*}{ الخريف } & 10.7 & $r \leqslant . r$ & 7. & q.V & 7.1 & $0 . Y$ & 1.1 & $0 . r$ & r..人 & \\
\hline & IV.e & M $1 \leqslant 0$ & 1.9 & $1 \% .1$ & 7.0 & \& & 1.0 & 0.10 & Ml. $1 \mathrm{e}$ & المتوسط \\
\hline
\end{tabular}

المصدر: الهيئة العامة للأرصاد الجوية بالقاهرة.

وتمتاز الرياح الغربية بزيادة سرعتها، كما أنها رطبة ومشبعة ببخحار الماء، مما يؤدى إلى

استقرار الرمال وقلة حركتها.

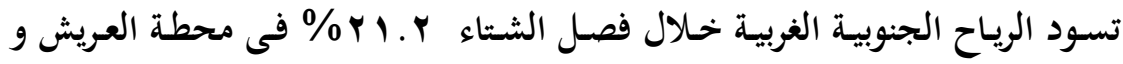

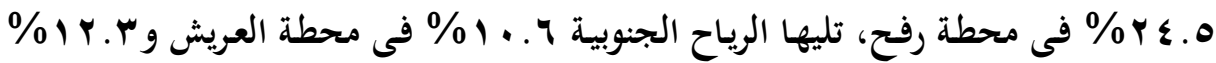

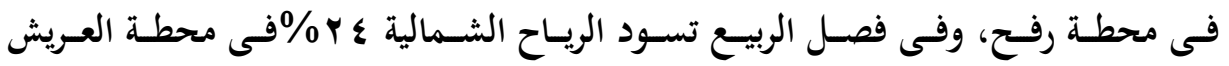

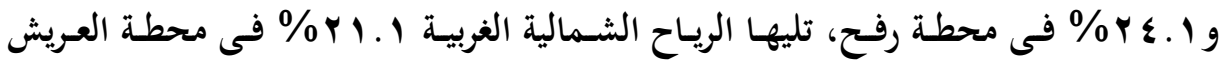
r.r r.\% فى محطة رفح، كما تسود خحلال هذا الفصل الرياح الخماسينية وهى رياح شديدة، تسبب عواصف ترابية، تؤثر بشكل واضح فى تشكيل سطح الأرض.

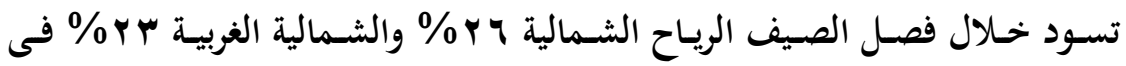

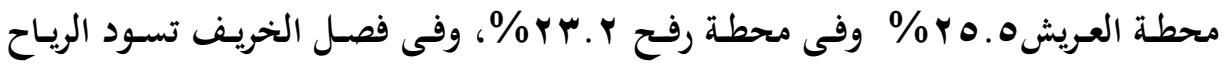

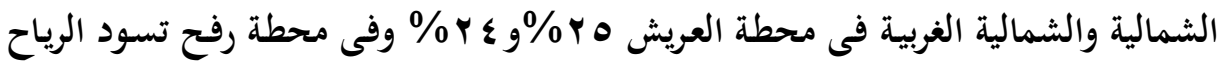

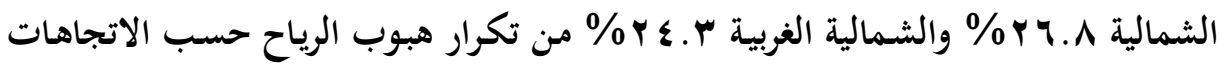
على منطقة الدراسة. تؤدى الرياح التى تتعرض لها منطقة الدراسة إلى تعرض سطح البحر لأمواج مصاحبة للأنواء والعواصف البحرية، التى يعقبها عمليات نحت وتآكل للشـاطئ فى بعض المواضـع وزيادة عمليات الإرساب فى مواضع أخرى. 
تتعرض منطقة الدراسة إلى أمطار المنخفضات الجوية الإعصارية التى تتباين تبايناً

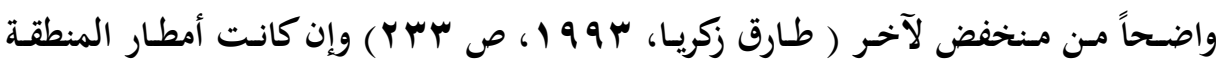

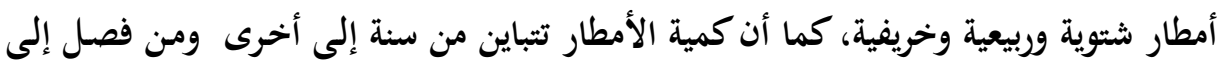

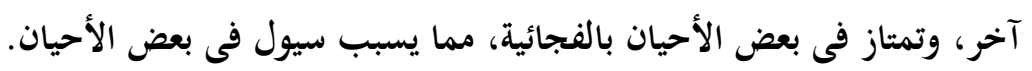

يتضح من الجدول رقم (T) و(الشكل ه) أن المنطقة يغلب عليها الجفاف بصفة

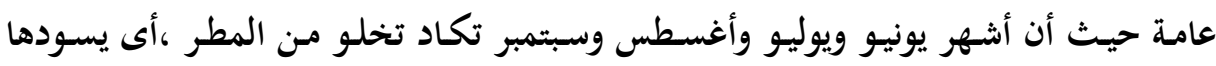

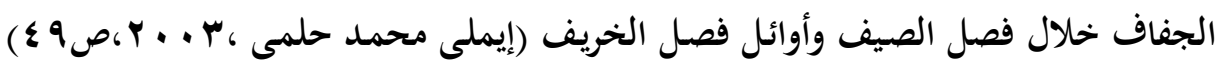
بينما تزداد كمية المطر خلال شهور الشتاء والربيع ( ديسمبر ويناير وفبراير ومارس ).

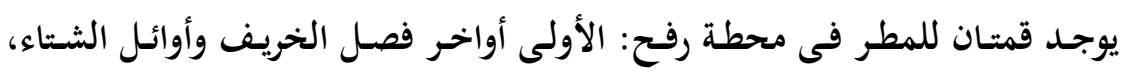

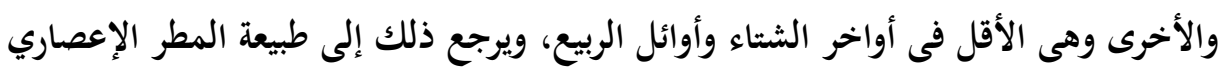

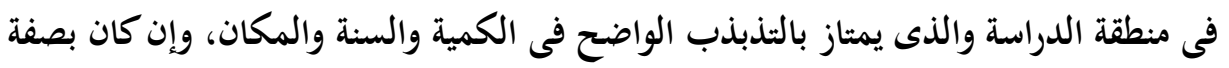
عامة تزداد كمية الأمطار كلما اتجهنا من الغرب إلى الشرق باتجاه محطة رفح.

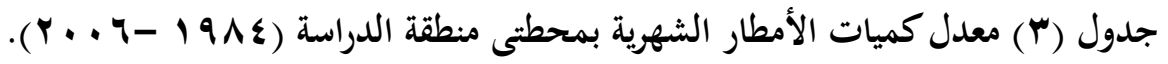

\begin{tabular}{|c|c|c|c|c|c|c|c|c|c|c|c|c|c|}
\hline$\underline{\underline{E}}$ & 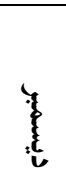 & t. & 茧 & 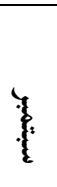 & $\&$ & $z_{i}^{2}$ & 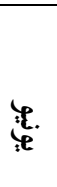 & 造 & te & $\frac{\xi}{\delta}$ & $\frac{\pi}{6}$ & . & | \\
\hline 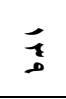 & $\hat{\dddot{\prime}}$ & $?$ & $\therefore$ & $\dot{i}$ & $\therefore$ & 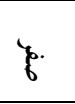 & है & $\exists$ & $?$ & $\bar{r}$ & $?$ & $?$ & $\underline{\underline{\varepsilon}}$ \\
\hline 1 & $\stackrel{?}{\vdots}$ & $\stackrel{3}{0}$ & 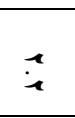 & t. & $\xi$ & $\xi$ & 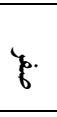 & $\vdots$ & $\bar{m}$ & 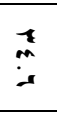 & 3 & ב & శ్ \\
\hline
\end{tabular}

المصدر : الهيئة العامة للأرصاد الجوية بالقاهرة. 

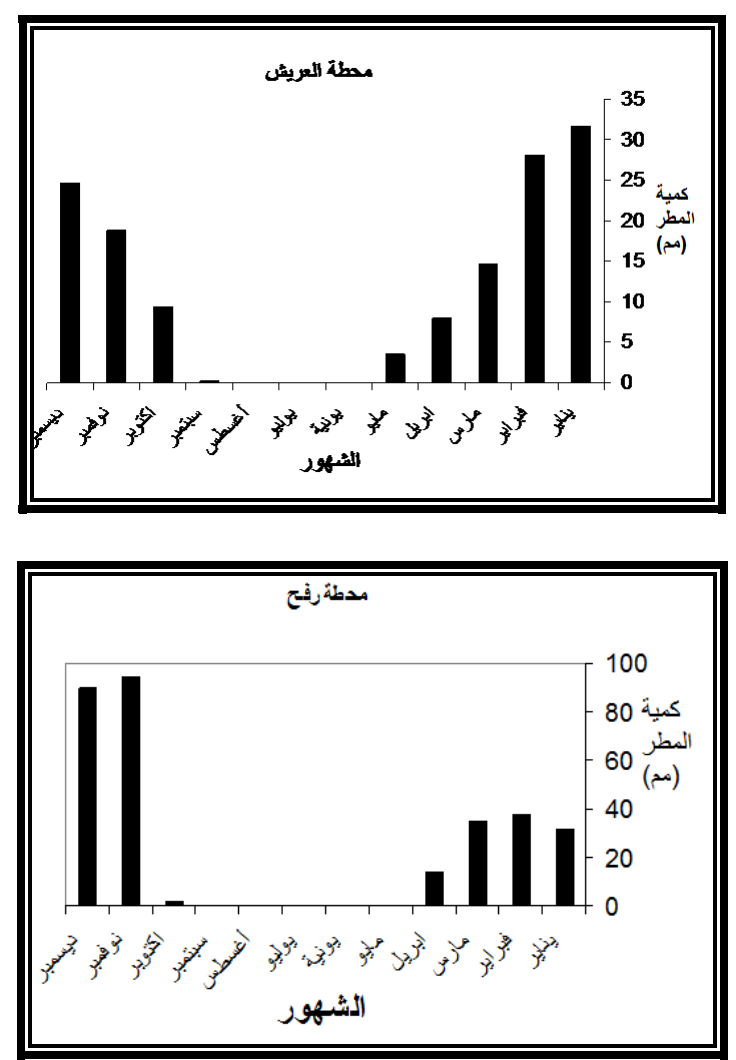

شكل (•) معدل كميات الأمطار الشهرية بمحطتى منطقة الدراسة.

خلاصة القول: إن للأمطار تأثيراً مباشراً وغير مباشر على الشريط الساحلى لمنطقة الدراسة، وذلك لأنها تعمل على انزلاق حبيبات رمال الشاطئ باتجاه البحر حسب الانحدار العام، مما يجعلها فريسـة سهلة لنحت وتآكل الأمواج وجرف هذه الرمال، وبالتالى يصسبح الشاطئ مستوي، مما يؤدى إلى تغلل المياه باتجاه الثاطئ.

كما تؤدى الأمطار إلى إذابة الأملاح، التى تتخلل رواسب الحجر الجيرى وخاصة من خلال الفواصل والشقوق والمسام، مما يؤدى إلى انفصال الكتل الصخرية وانجرافها بواسطة الأمواج ومياه الأمطار الغزيرة. 
ثالثاً: العمليات الجيومورفولوجية.

تلعب العمليات الجيمورفولوجية دوراً واضحاً فى تشكيل ساحل منطقة الدراسة، وقد

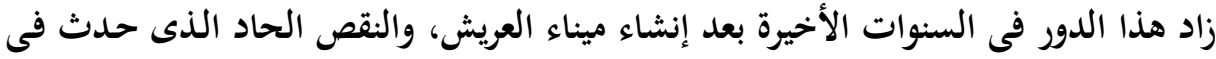

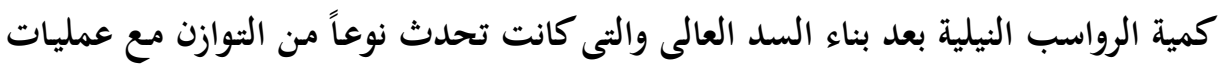

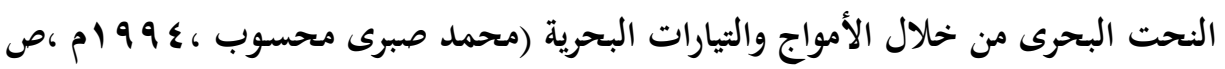
صب ا ، ـ ( ) وفيما يلى دراسة عن دور العمليات الجيومورفولوجية فى تشكيل الساحل.

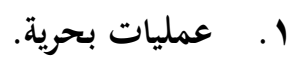

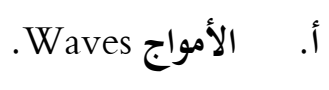

تُعد الأمواج من العوامل المهمة المؤثرة فى الثواطئ، فعندما تزداد سرعة الأمواج

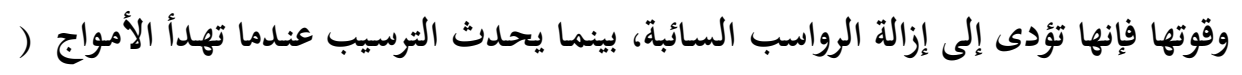

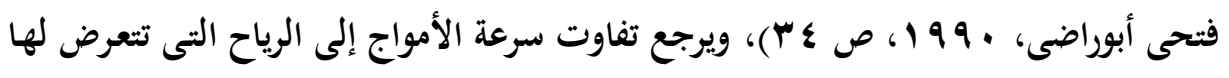

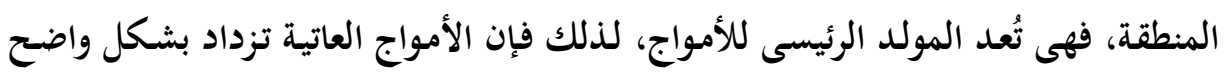

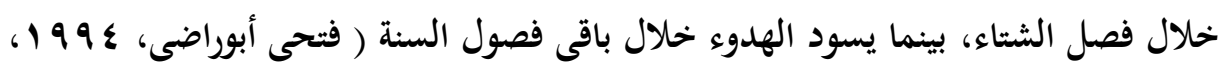
ص ص (O)

يتراوح ارتفاع الأمواج أمام سواحل منطقة الدراسة بين ه م و $\wedge$ م، ويزداد ارتفاعها

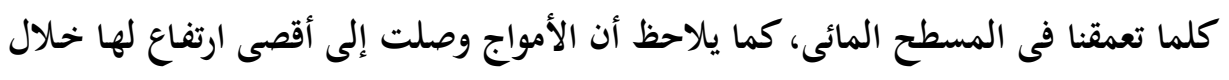

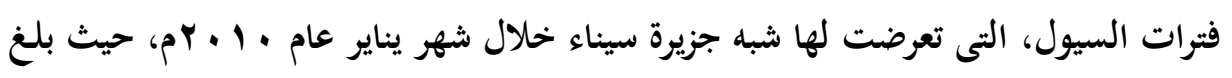

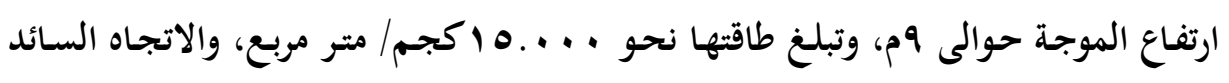

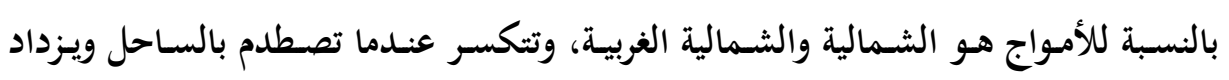

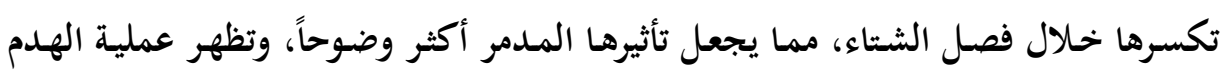

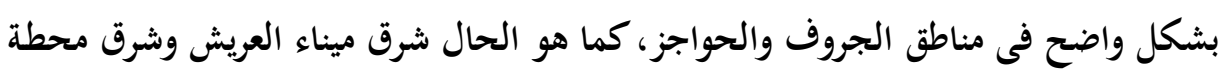

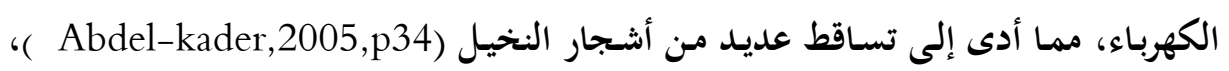
يلعب اتجاه خط الشاطئ دوراً بارزاً فى مدى تأثير الأمواج وفاعليتها، فعندما تكون الكون الأمواج 
متعامدة على خط الشاطئ يشتد النحت بشكل واضح (Abou - Raddy,1989 ). وإن

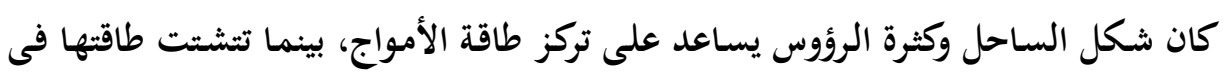

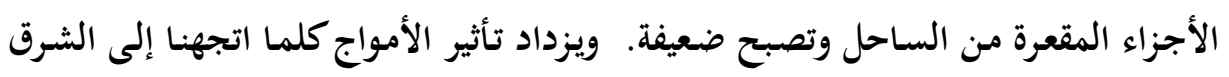

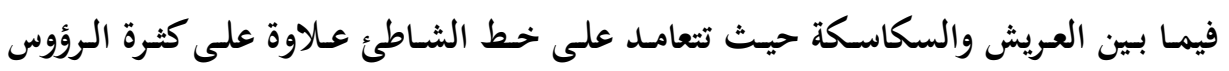

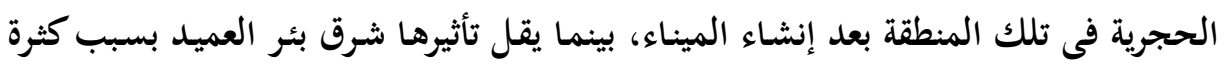
الكثبان الرملية وإلى الغرب من أبو سجال حتى الحدود الغربية للمنطقة حيث يمتاز الشريط الساحلى بالتقعر.

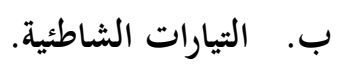

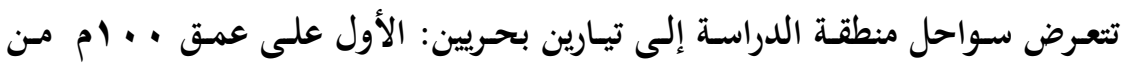

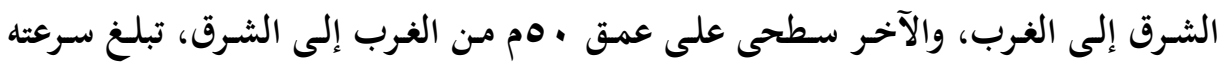

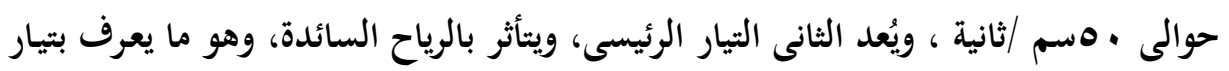

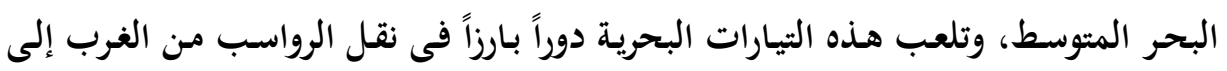

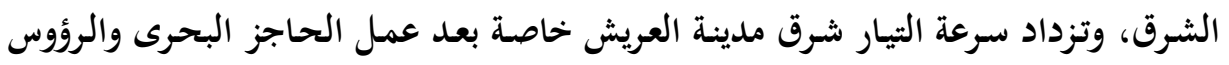

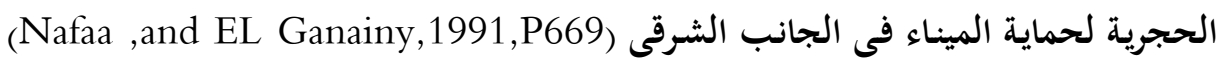

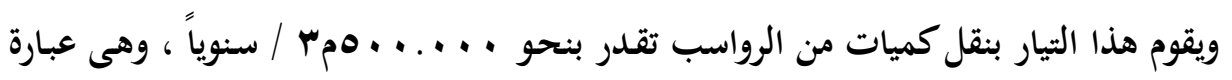
عن رواسب نواتج النحت البحرى. ج تيارات المد والجزر.

تتعرض منطقة الدراسـة إلى تيارات المـد والجزر مثلها مثل بـاقى المناطق السـاحلية حيث تتعرض إلى مدين وجزرين كل يوم قمرى( النصف يومى) ( يوسف فايد، محمد صبرى

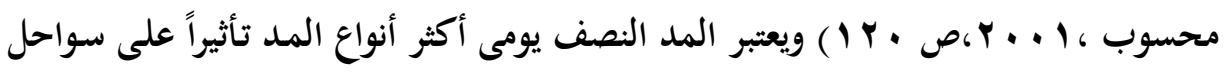

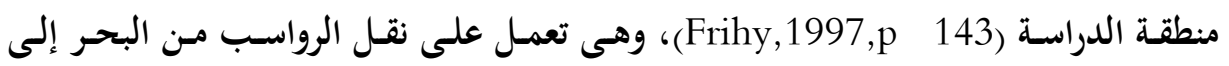

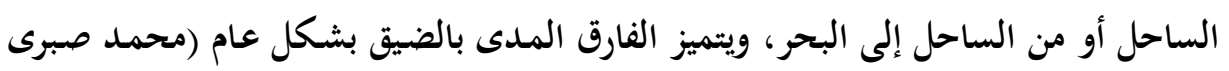

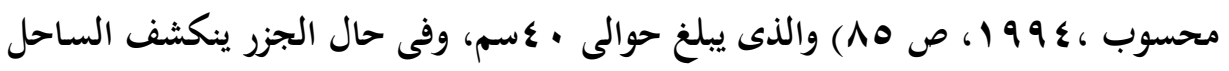

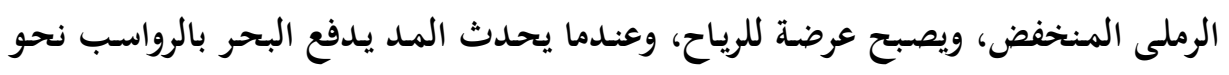


الساحل فى بعض المناطق خاصة المنخفضة والمستوية السطح، بينما فى بعض المناطق عند

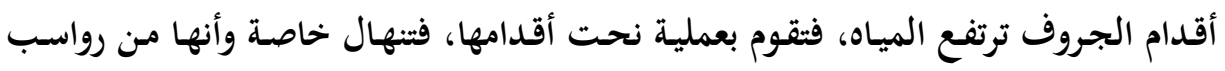
رملية مفككة وهشة سهلة الانهيال صورة ( (1).

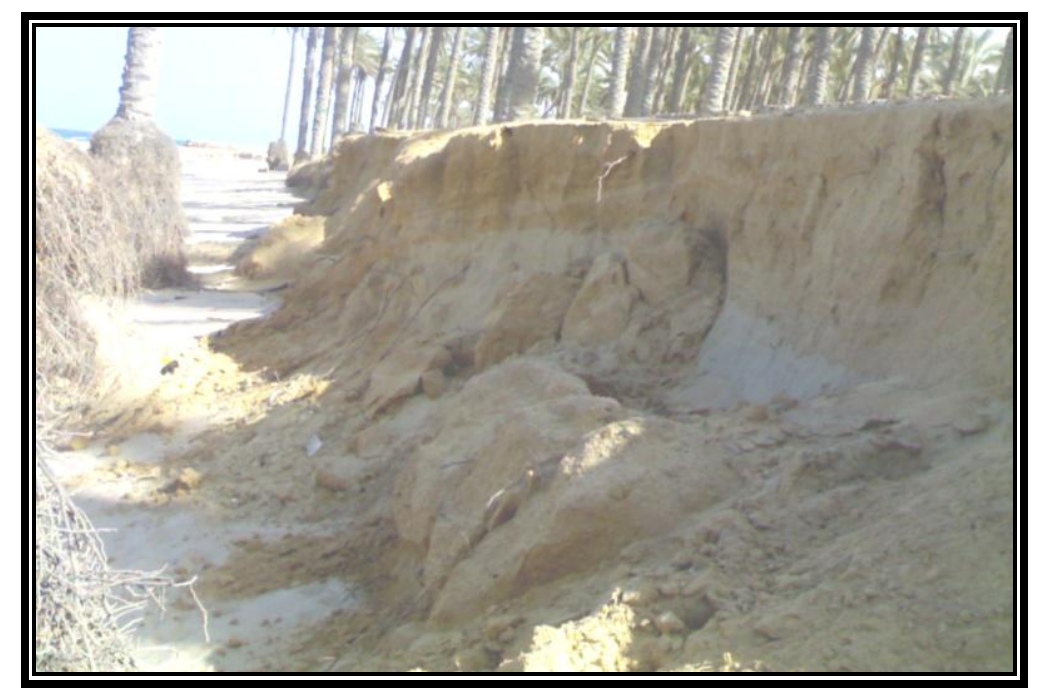

صورة ( 1) انهيال الرواسب نتيجة قنوات المد عند أقدام الجروف

Y ا عمليات جيومورفولوجية قارية.

أ أتجوية.

تُعـد التجويـة مـ أهـم الأخطار الجيومورفولوجيـة المؤثرة فى منطقـة الدراسة وخحاصـة التجوية الملحية سواء أكانت طبيعية أو بشرية، فهى تحدث نتيجة نمو البلورات الملحية التى تملأ الشقوق والفواصل أو عن طريق تفكك وتحلل التكوينات السطحية وتحولها من الحالة المتماسكة إلى المفتتة والمحللة صورة (ץ).

تشرف منطقة الدراسة مباشرة على ساحل البحر المتوسط، وكان لهذا الموقع المميز أثره الواضح فى نشاط ونمو البلورات الملحية، خاصة وأن المنطقة تتعرض إلى تفاوت ومدى لهي

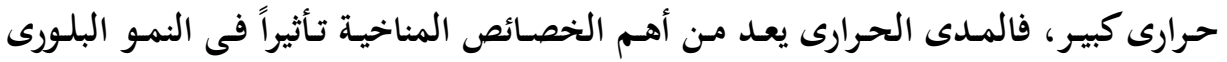

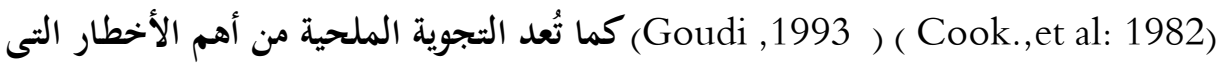


تمارس دورها فى تفكك الصخور، حيث تتراكم الأملاح فوق أسطح الصخور والسبخات

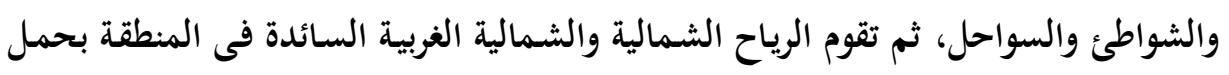

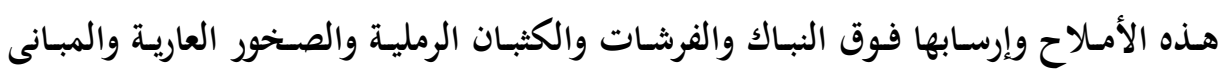
والمنشآت المنتشرة على طول الساحل مما يؤدى إلى نشاط دور التجوية الملحية من خلال

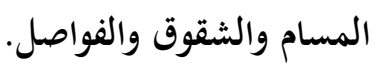

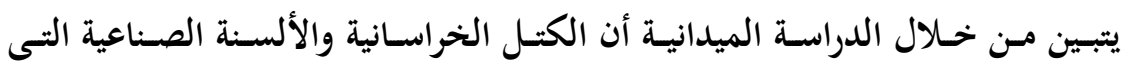

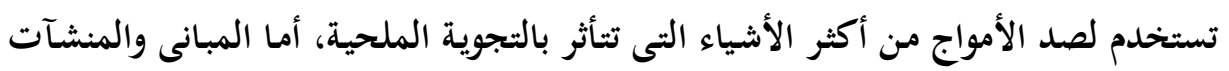

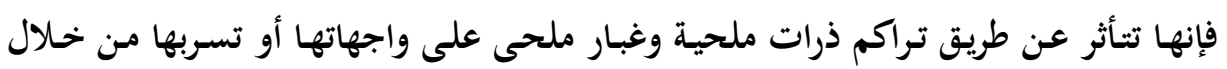

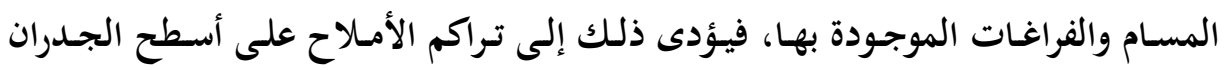
وداخل الفجوات والمسافات البينية، والتى تعمل على انفصال الغطاءات الأسمنتية للواجهات

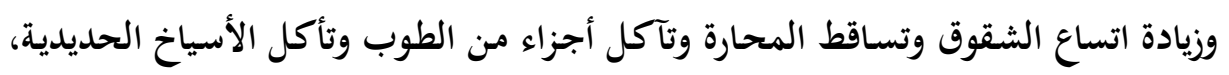
وبالتالى تعرض المبانى والمنشآت إلى الانهيار والثدمير صورة (ب). كما تؤثر التجوية وخاصة الملحية على الطرق، ويتمثل ذلك بواسطة الخاصية الشعرية

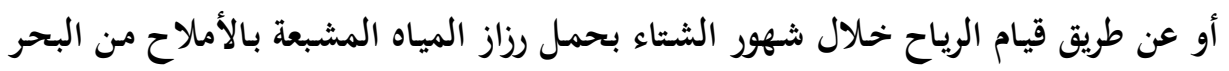
وسقوطها على الطريق، فيؤدى ذلك إلى تشققات بالطبقة الإسفلتية وتكسرها كما هو الحال الحيال فى طريق العريش رفح. 


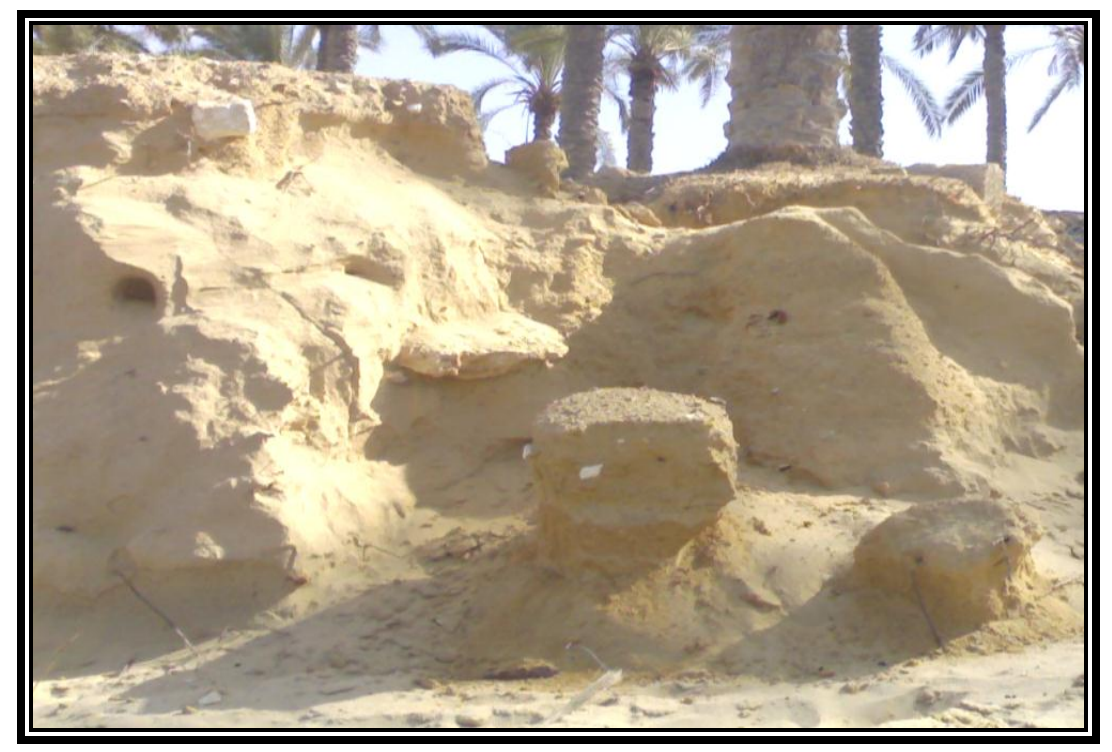

صورة(ץ) دور التجوية فى تفكك الصخر وتحلله شرق مدينة الريسة

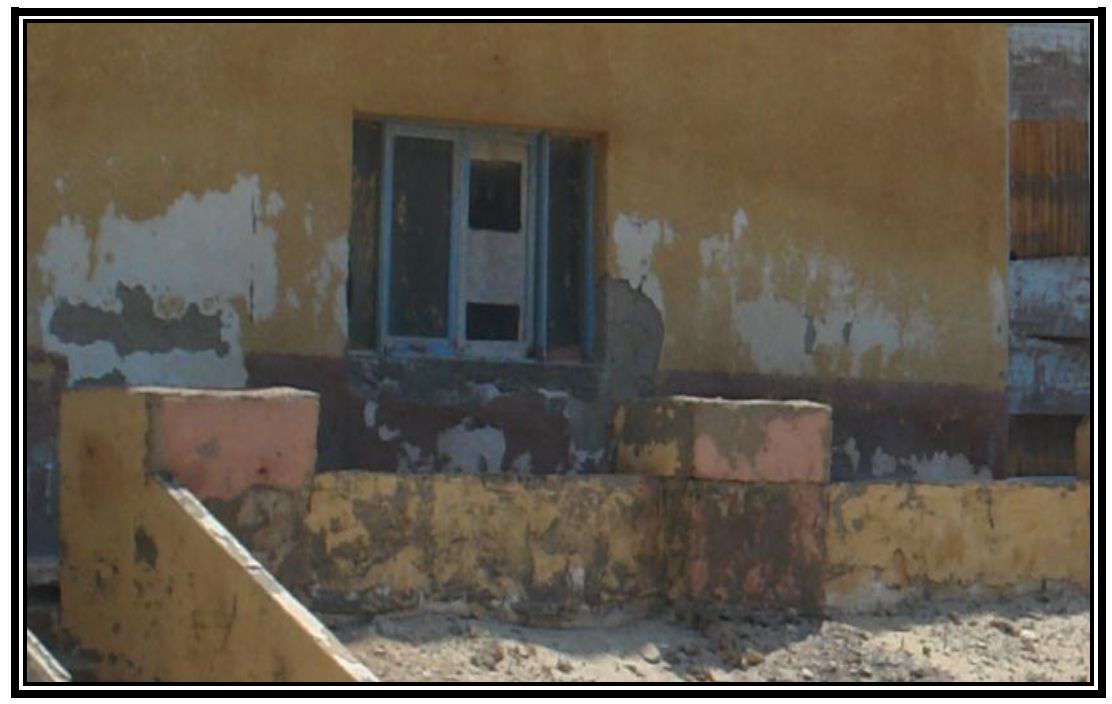

صورة (T) توضح نشاط عمليات التجوية شرق ميناء العريش

$$
\text { ب الرياح. }
$$

تلعب الرياح فى منطقة الدراسة دورين: الأول تشكيل الأشكال الرملية وحركتها ودفع الحبيبات الرملية الدقيقة، التى تنطاير فى الفضاء، فنصطدم بالمبانى والمنشآت و تُعد الرياح 
الشمالية والشمالية الغربية أهم أنواع الرياح السائدة تأثيرا، فهى تقوم بحمل الحبيبات الرملية

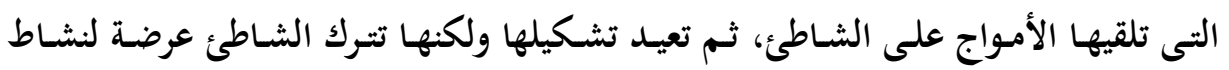

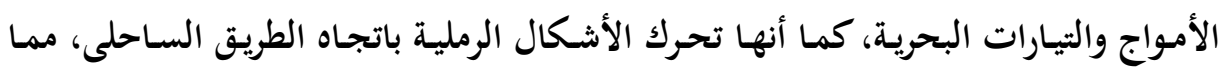
يؤدى إلى غلقه أو تغطية بعض المزارع.

أما الدور الثانى: فيتمثل فى اصطدام الرياح بالمبانى والمنشآت الممتدة على طول الشريط الساحلى، كما هو الحال فى منطقة الريسة والسكاسكة والشيخ زويد ورفح، وتمتاز

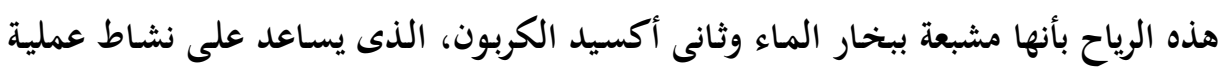
التميؤ ونمو البلورات الملحية والنشاط التجوية الملحية.

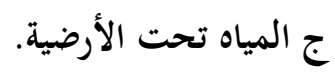

تمثل المياه تحت الأرضية عاملاً من العوامل المهمة فى تشكيل سطح الأرض وإذابة بعض أنواع الصنور وخاصة رواسب الحجر الجيرى علاوة على تكوين غطاءات ملحية نتيجة

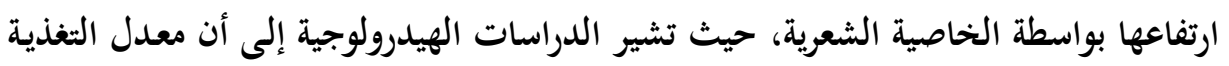

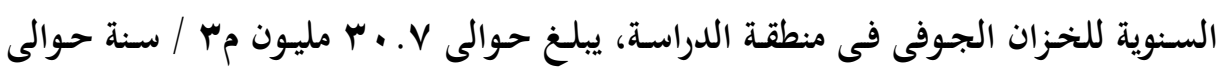

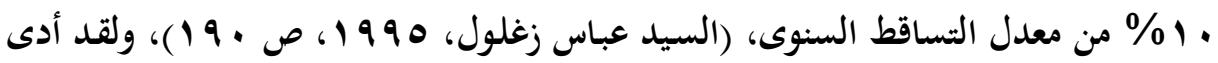

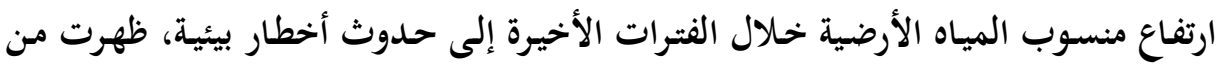

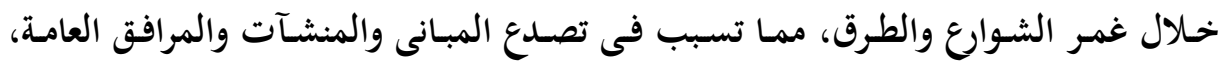

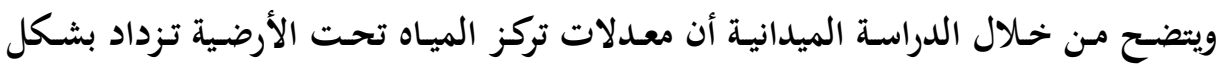
واضح كلما اتجهنا من الشرق إلى الغرب، كما أنها تزداد داخل الأحياء والمناطق السكنية

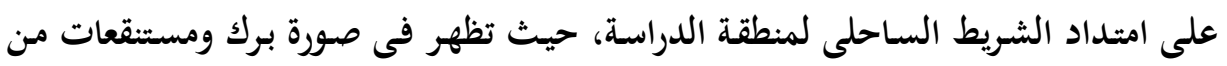

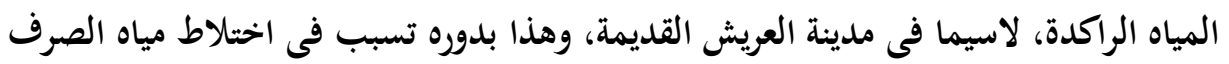

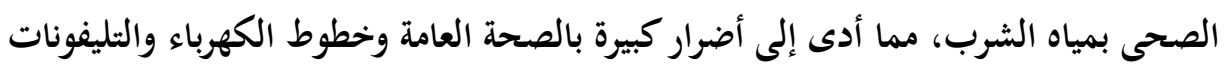
وتدمير التربة السطحية وتشقق الطرق العامة وهبوطها وتصديات التربات بالمنشآت والمبانى وإنتاج التربة ونشاط عمليات التجوية الكيميائية (Sami.,1995,p.113). 


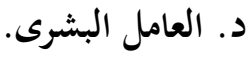

يتعرض كوكب الأرض إلى ارتفاع واضـح فى درجـات الحرارة، ممـا ينتج عنده ذوبـان

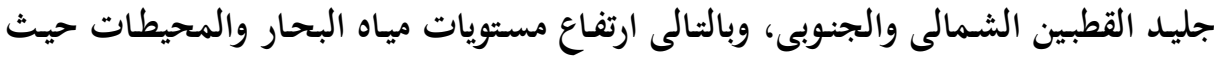

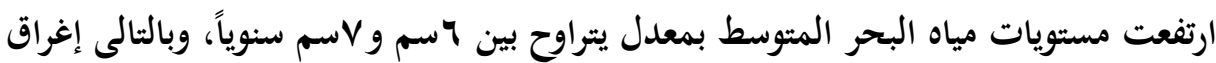

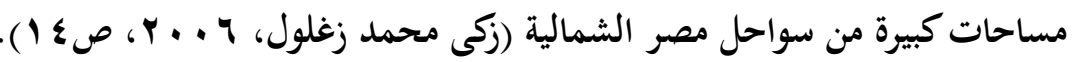
كمـا أن الإنسان تـدخل بشـكل مباشـر عن طريق بنـاء مينـاء العريش ومحطة كهربـاء وإقامة حاجز بحرى وعديد من الكتل الخراسانية داخل مياه البحر، التى ساعدت على زيادة

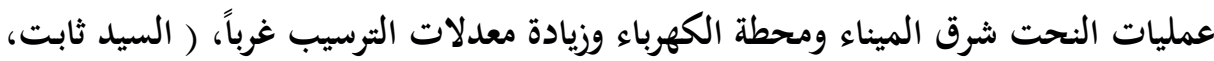

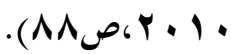

\section{رابعاً: جيومورفولوجية الساحل.}

ينتشر على امتداد ساحل البحر المتوسط من شرق بحيرة البردويل حتى مدينة رفح العديد من الأشكال الجيومورفولوجية، ومن خحلال الدراسة الميدانية والموزايك الجوية مقياس

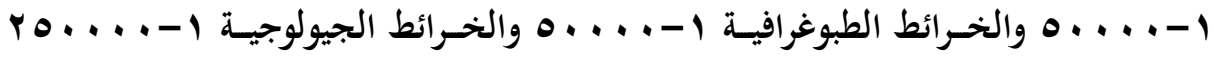

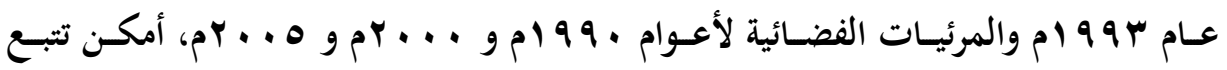

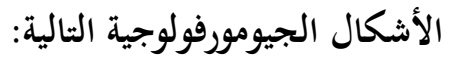
ا ـ أشكال ناتجة عن النحت البحرى. أ. الجروف البحرية Marin Cliffs.

تتكـون الجـروف نتيجـة اخستلاف التعاقـب الطبـاقى لرواسـب الصـخور، حيـث تقـوم

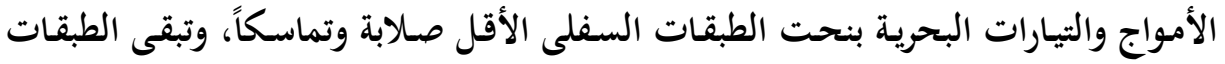
الصـلبة معلقـة، ثم مـا تلبـث أن تنهار وتتسـاقط، وهو مـا ينتج عنسه تكوين الجـروف البحريـة

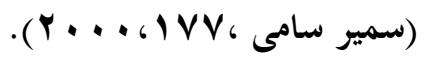

تم قياس عدد || قطاعاً موزعة على امتداد منطقة الدراسة من الغرب إلى الشـرق

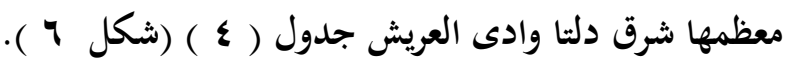


يتضح من الجدول ( \& ) أن أطوال قطاعات الجروف تتفاوت من منطقة إلى أخرى

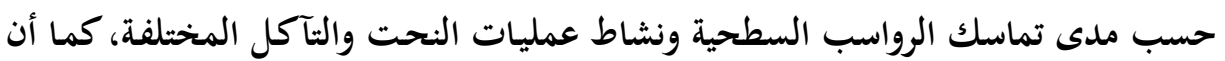

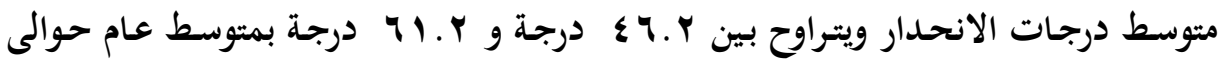

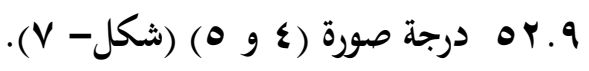

جدول (ع) أبعاد الجروف البحرية ومتوسط انحدارها فى منطقة الدراسة

\begin{tabular}{|c|c|c|c|c|}
\hline متوسط درجة & متوسط ارتفاعها & 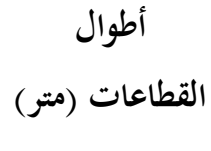 & عدد & مواقع قطاعات \\
\hline$\varepsilon Y . Y$ & 9.0 & r & $r$ & بئر المساعيد \\
\hline or & 0.1 & v & 1 & بئر أبو غازى \\
\hline or & 0.0 & 11 & $r$ & بئر الخروبة \\
\hline or.1 & $\varepsilon . Y$ & 7 & 1 & بئر العمائد \\
\hline$\varepsilon 9 . V$ & $r . r$ & 0.7 & 1 & بئر أبو سرية \\
\hline $0 \leqslant .1$ & r.l & $\varepsilon . \wedge$ & 1 & المصيدة \\
\hline $71 . Y$ & Y.A & r.o & 1 & الشيخ زويد \\
\hline 00.7 & r.l & V.r & 1 & بئر الأحيمر \\
\hline or. 9 & $\varepsilon .0 V$ & VY.Y & 11 & المجموع \\
\hline
\end{tabular}

المصدر: الدراسة الميدانية. 


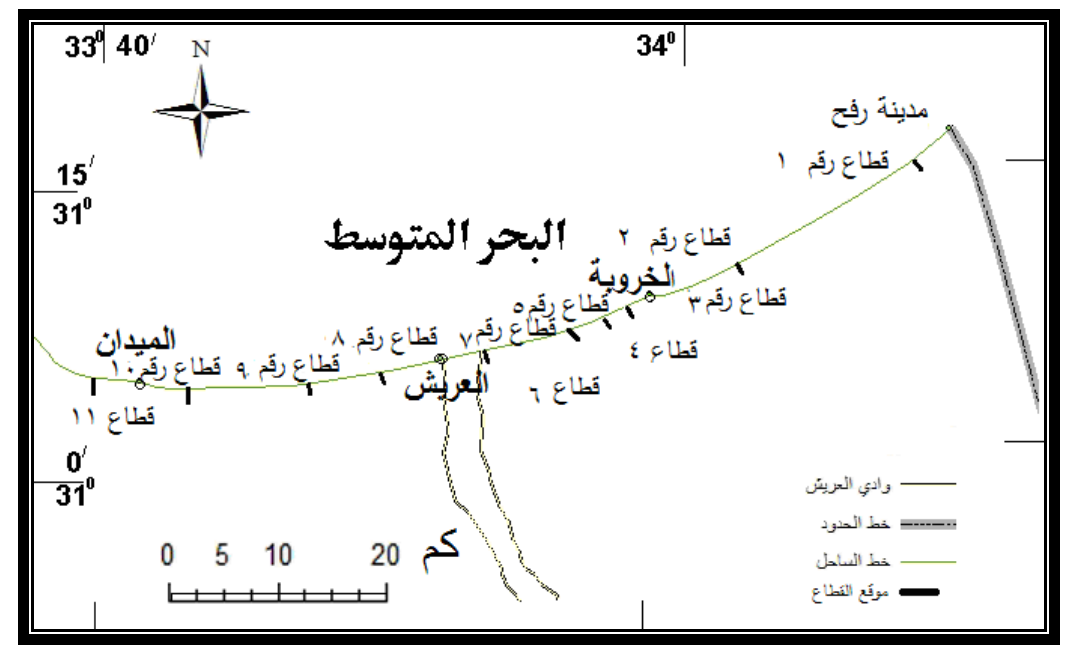

شكل (؟) مواقع قطاعات الجروف البحرية بمنطقة الدراسة

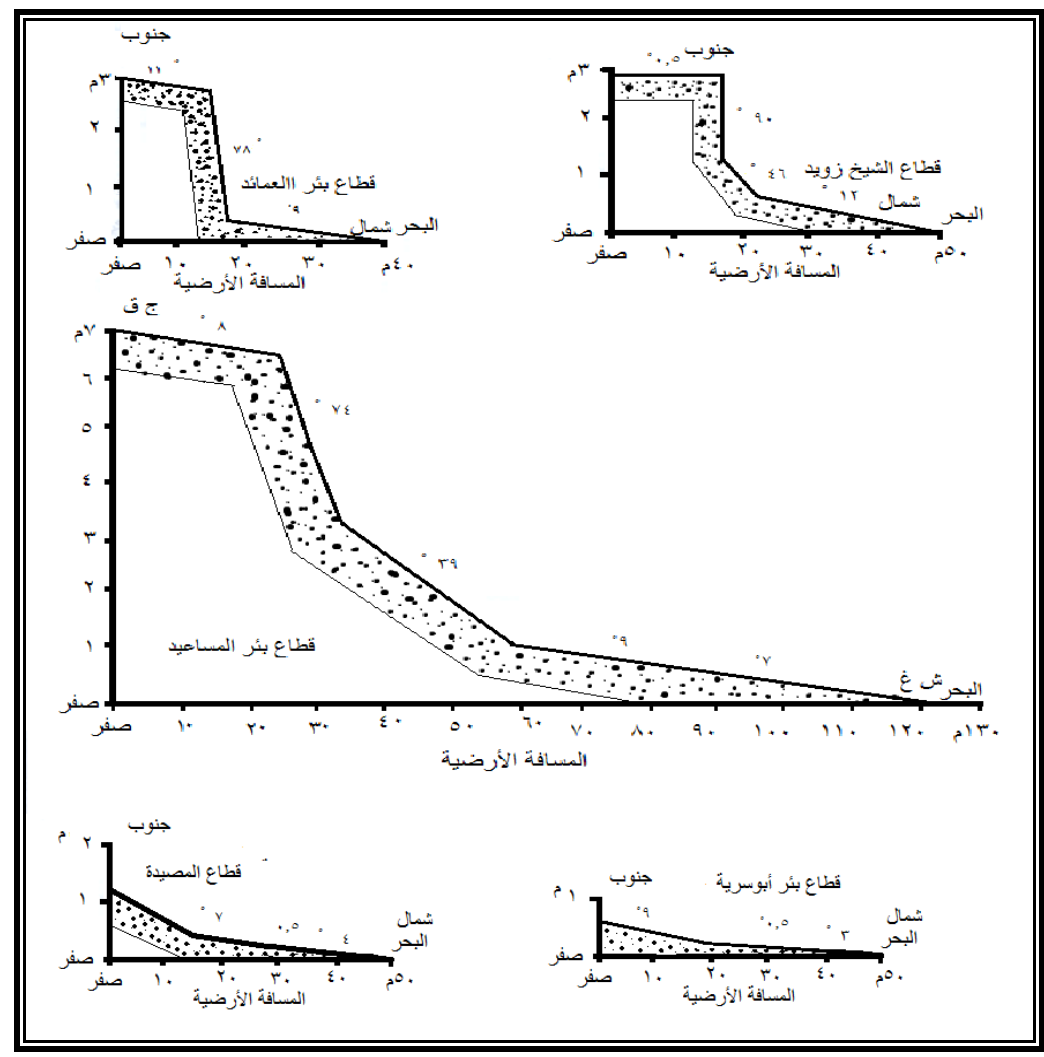

$$
\text { المصدر: قياس ميدانى }
$$


شكل (V) بعض قطاعات الجروف البحرية بمنطقة الدراسة رواسبها من

$$
\text { الرمل والحصى والرواسب البحرية }
$$

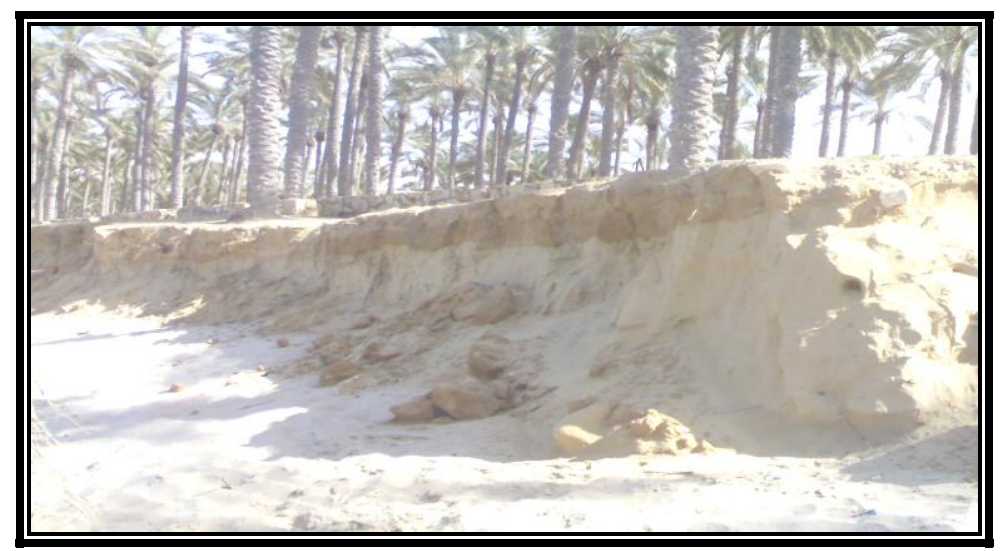

$$
\text { صورة (๕) جرف بحرى فى منطقة الريسة }
$$

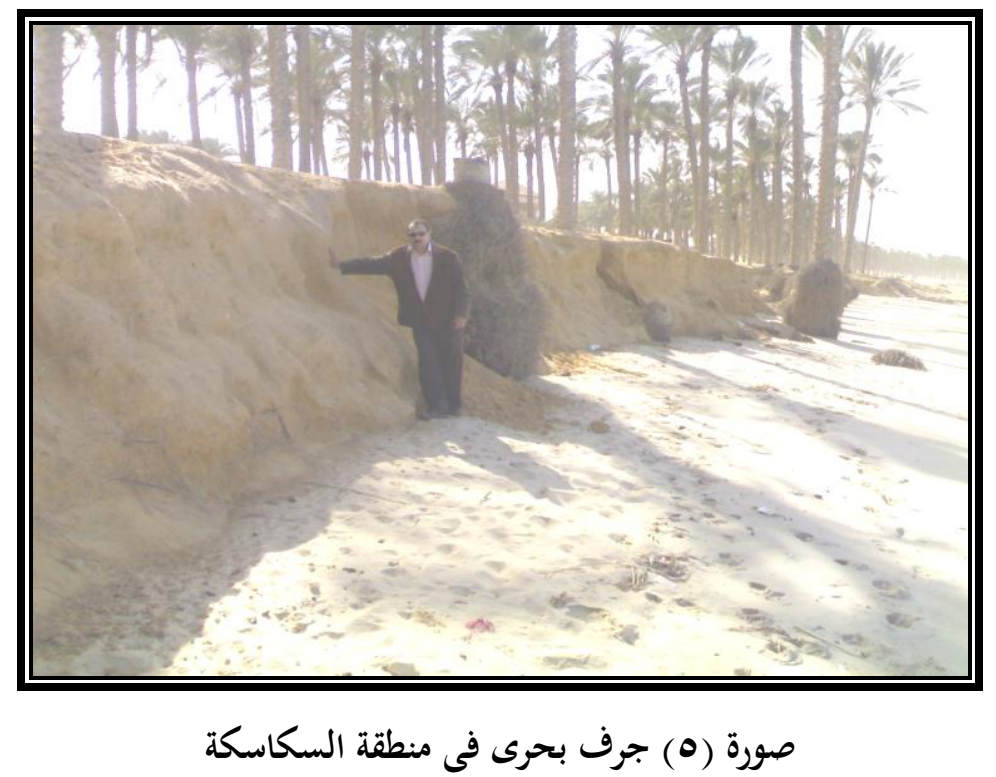

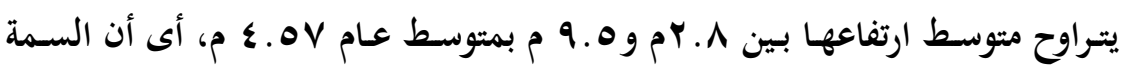

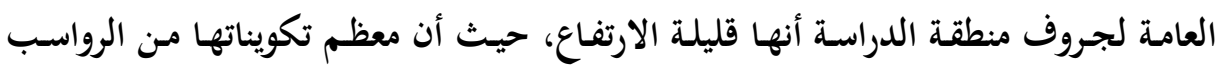
الرملية عند أقدام الكثبان الرملية، وبعضها من رواسب الحجر الجيري و الرواسب البحرية، 
وهي رواسب غير متما سكه في معظمها ضعيفة المقاومة لعمليات النحت، مما يؤثر بشكل

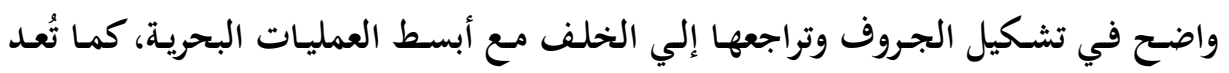

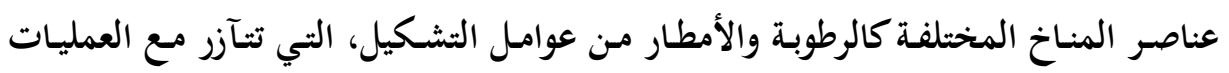

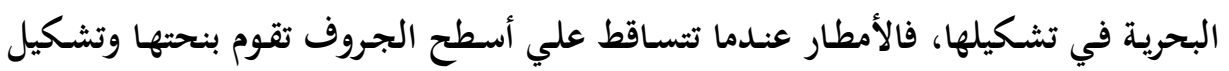

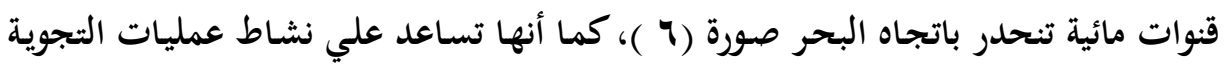

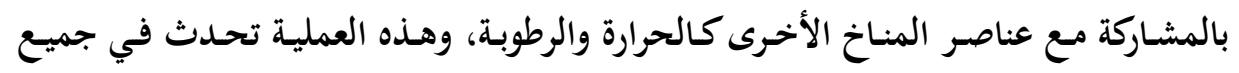
الأشكال الجيورفولوجيه المنتشرة علي طول الشاطئ.

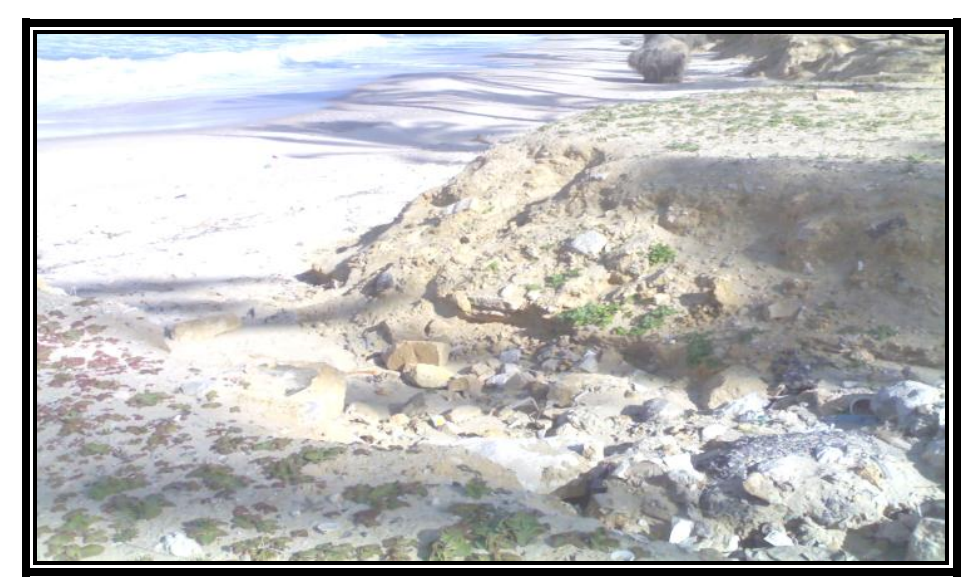

صورة (7) قنوات مائية بفعل الأمطار باتجاه البحر

ب ب - بأرصفة الشاطئية Shore Platforms

ترتبط الأرصفة الثاطئية بالجروف البحرية في معظم الأحيان نتيجة نشاط عمليات

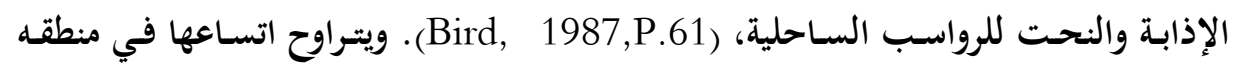

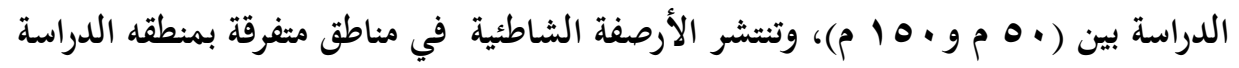

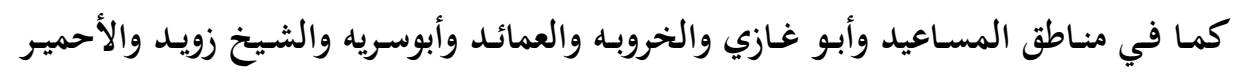

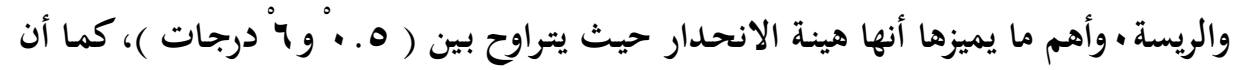


معظم رواسب من الحجر الجيري والرملي المغطي بالرواسب الرملية والجلاميد بالقرب من دلتا العريش.

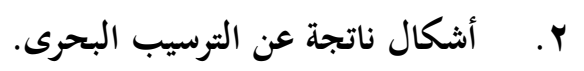

Shore أ. الشاطئ

يمتد شاطئ منطقة الدراسة من شرق بحيرة البردويل حتى غرب مدينة رفح بطول يبلغ

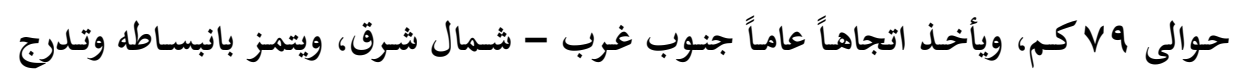

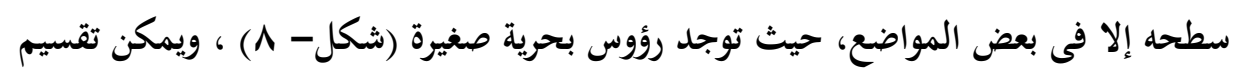

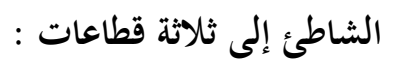

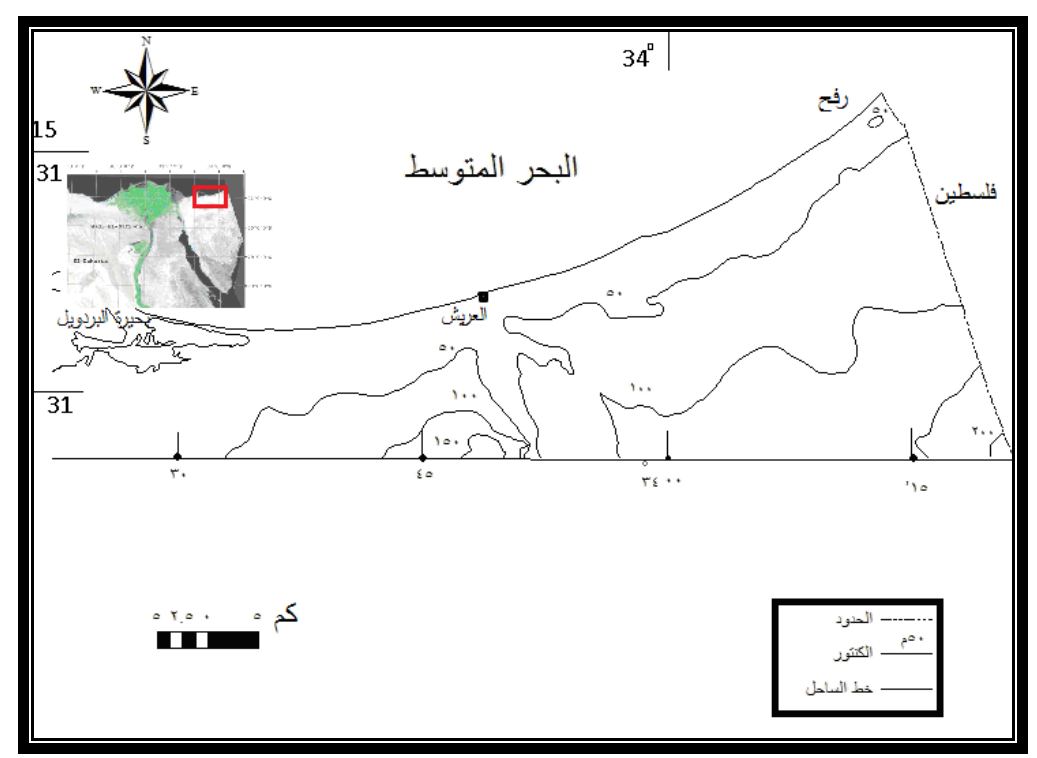

شكل (^) الخريطة الكنتورية لمنطقة الدراسة

I. قطاع يمتد شرق بحيرة البردويل حتى غرب دلتا وادى العريش.

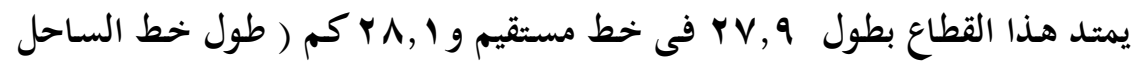

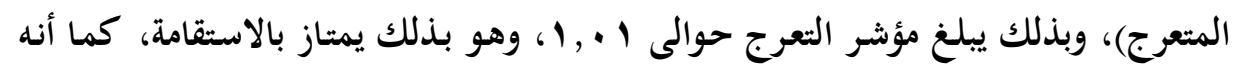

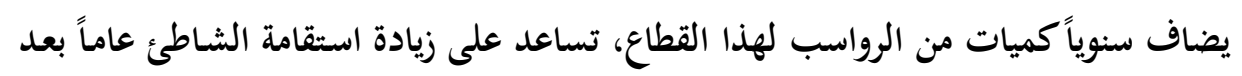




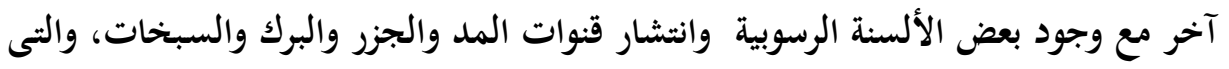

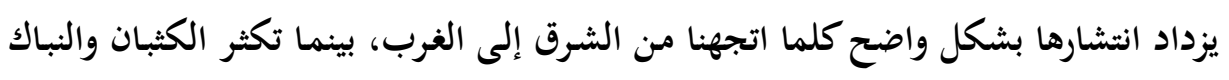

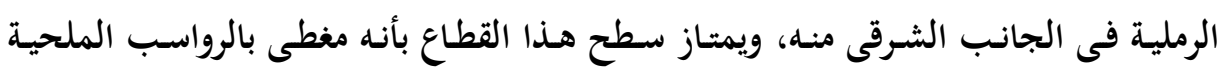

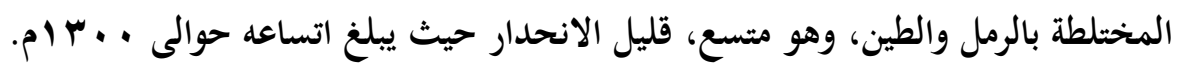

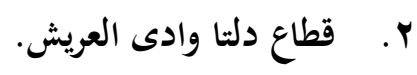

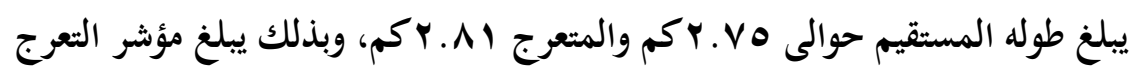

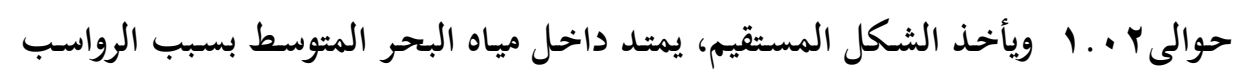

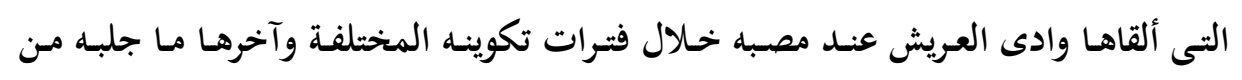

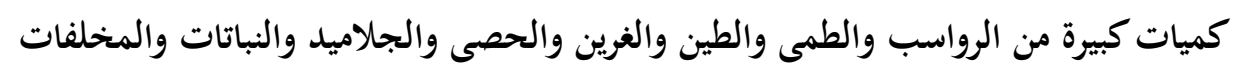

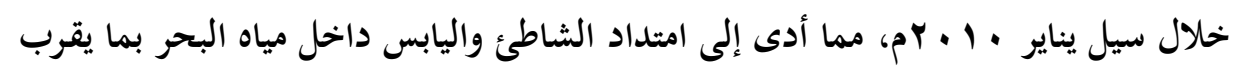

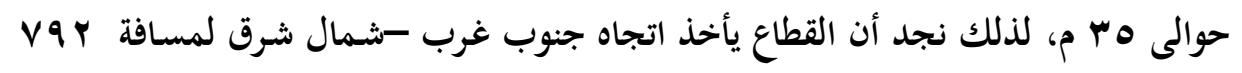

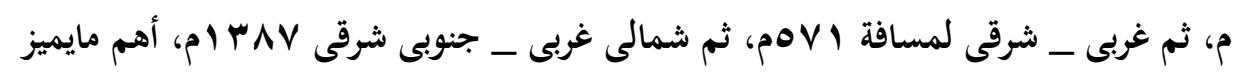

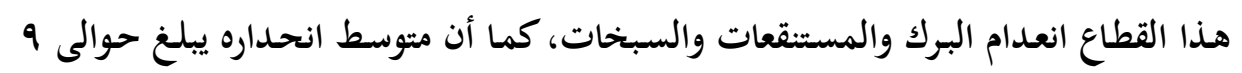
درجات، لأن سطحه الخارجى حديث النكوين لايتعلى عاماً واحداً صورة (V).

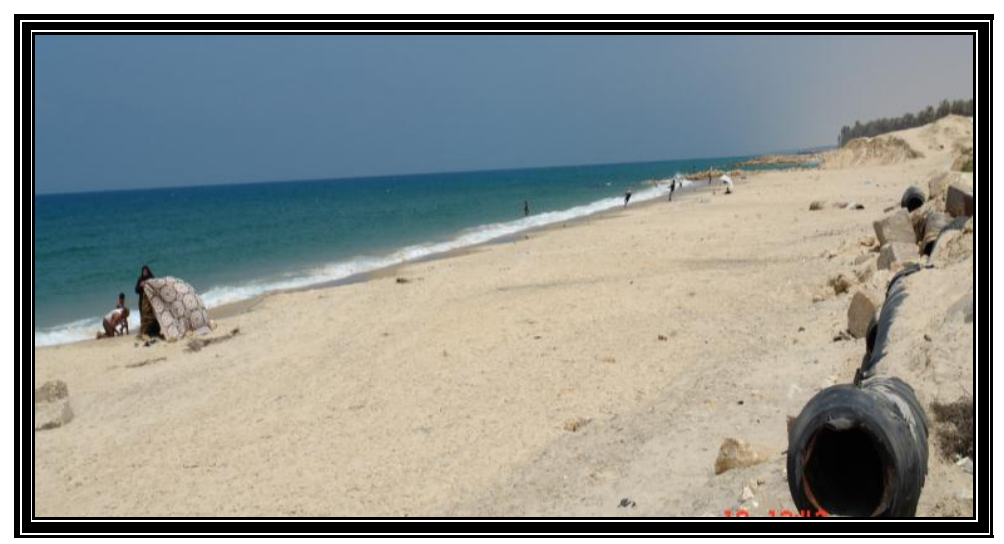

صورة (V) الشاطئ شرق دلتا وادى العريش 


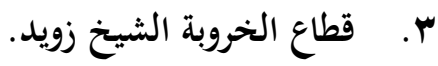

يبلغ طوله المستقيم حوالى ؟. ـ ـ كم والمتعرج ع ـ ـ ه كم، وبذلك يبلغ مؤشر التعرج حوالى \& • ـ ا، وهو يقع شرق دلتا وادى العريش حتى الحدود المصرية الفلسطينية، ويمتاز

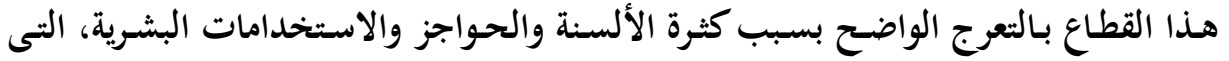

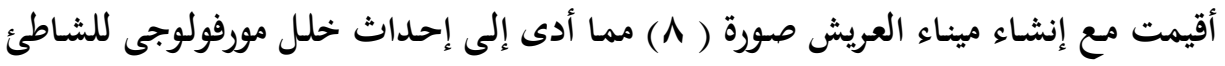

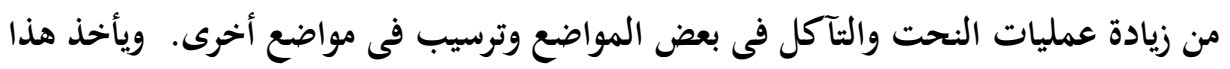

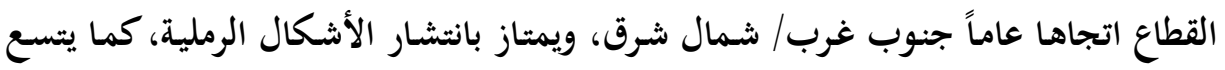

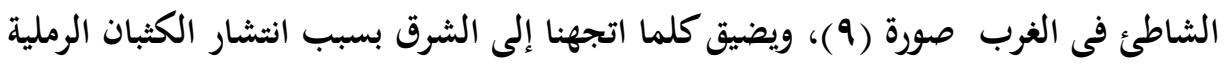

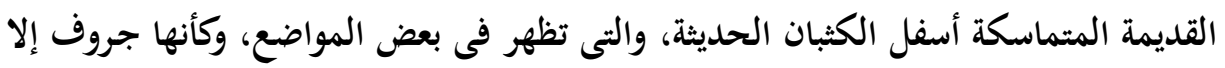
أن متوسط اتساع الساحل • • 9 م.

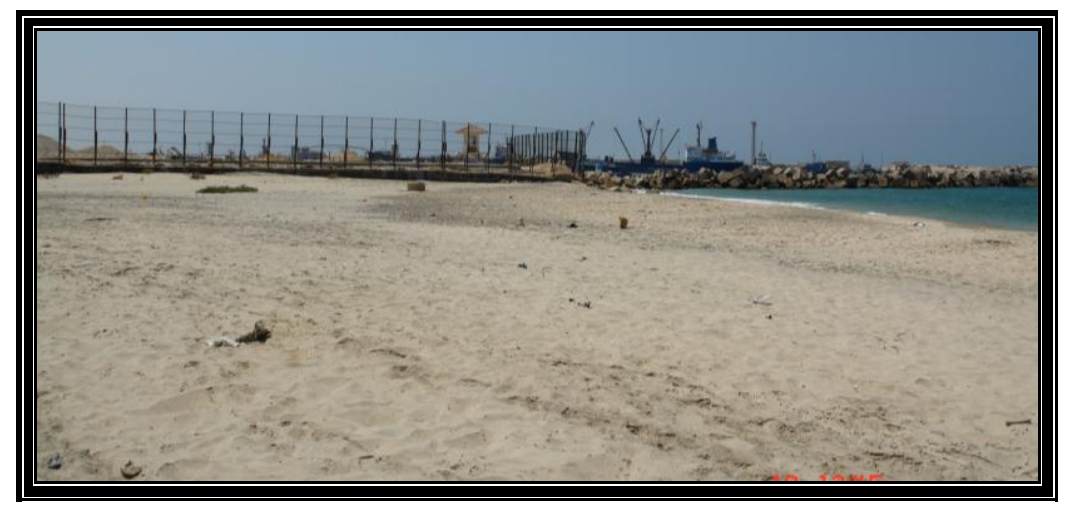

صورة ( A ) ميناء العريش ودورة فى عملية الإطماء 


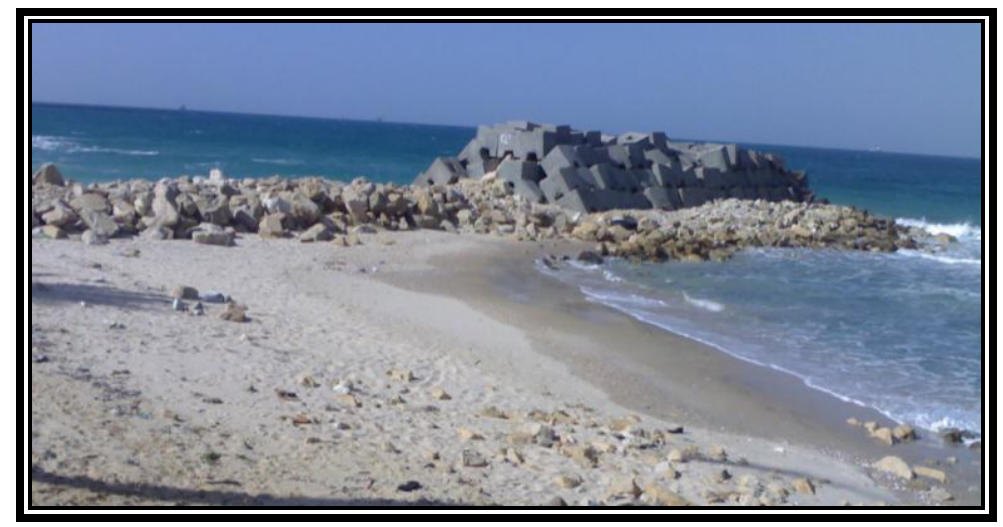

صورة (9) حاجز صخرى شرق ميناء العريش

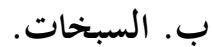

تمثل السبخات بمنطقة الدراسة شكلاً جيومورفولوجياً متميزاً، كما أنها تمثل خطراً طبيعيا على الاستخدامات البشرية على امتـداد الجانب الغربى من منطقة الدراسة، وينعدم

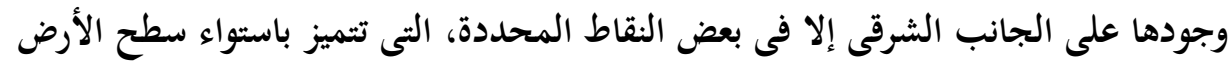

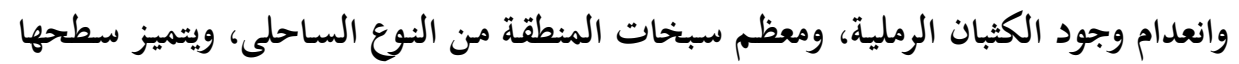
بالانحـدار الهين، الذذى يتراوح بين ه. • و و درجـات، وتغطيها فى معظم الأحوال قشـور

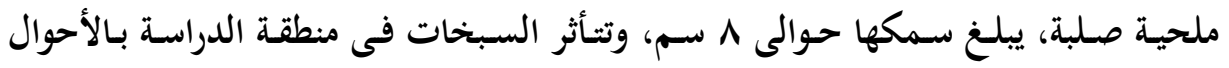

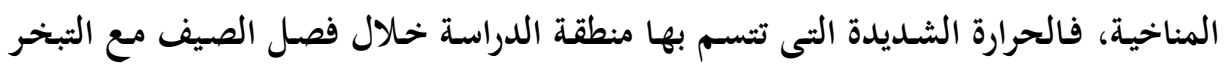
الشديد تساعد على تركز الأملاح فوق السطح.

كما تمثل السبخات خطراً جيوموفولوجياً على جميع الاستخدامات البشرية وذلك من

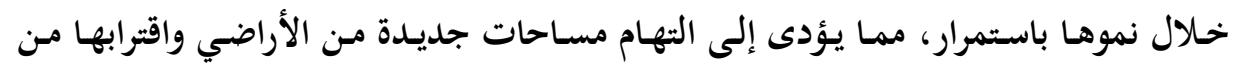

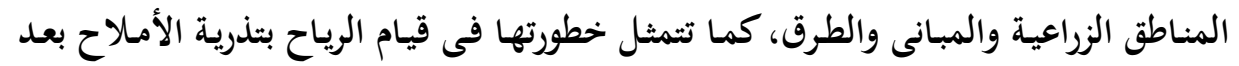
جفافها وإرسابها على مظاهر العمران المختلفة.

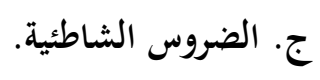

تتألف ضروس الشواطئ Beach cusps من الرواسب الشاطئة مثل الرمال الناعمة

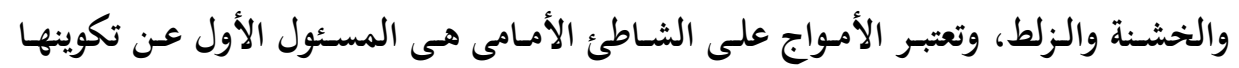




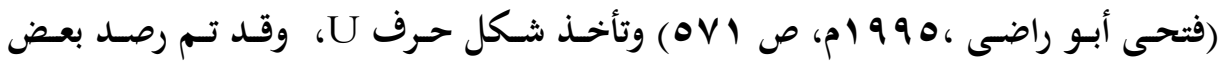

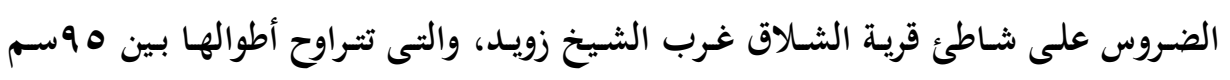
و \1 اسم ومتوسط العرض بينه هم سم و • 1 سم

صفوة القول: إن سطح منطق الدراسة يمتاز بالاستواء وقلة الانحدار وعدم وجود تلال

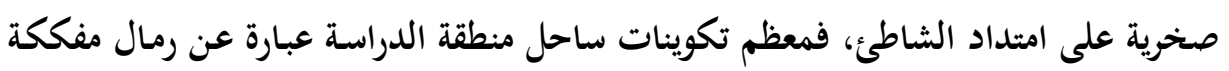

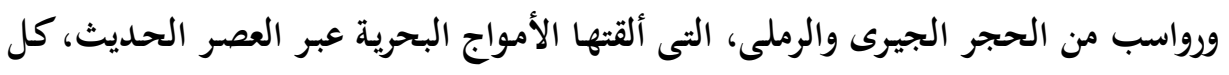

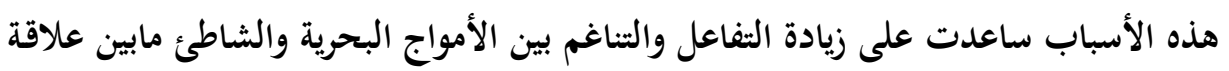

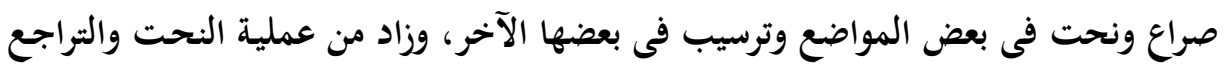

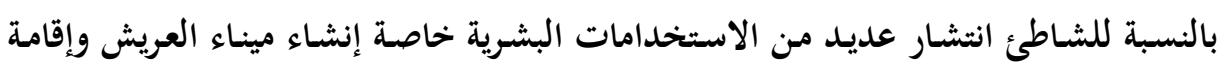

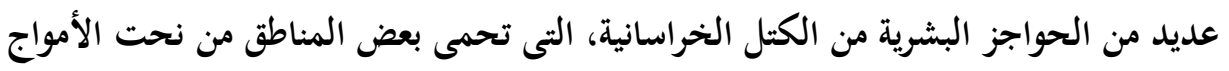
وتزيدها فى بعضها الآخر بسبب جيومورفولوجية الساحل. خامساً: التغيرات الجيومورفولوجية على الشاطئ. أ. تآكل ونحت الشواطئ.

يُعـد تأكـل ونحـت الشـواطئ مـن الأخطار الطبيعيـة القديمـة التى تعـانى منها منطقـة

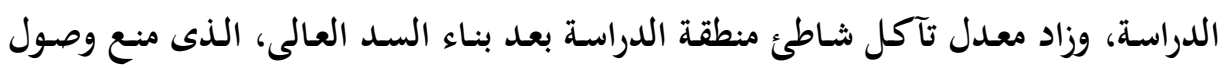

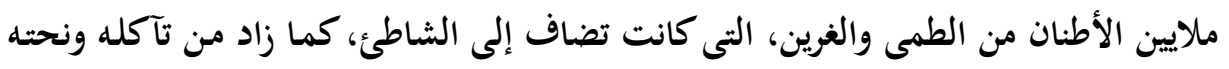

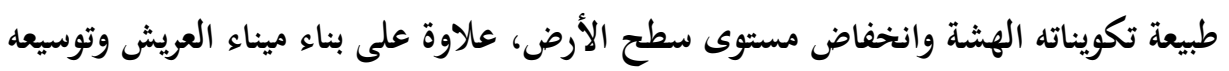

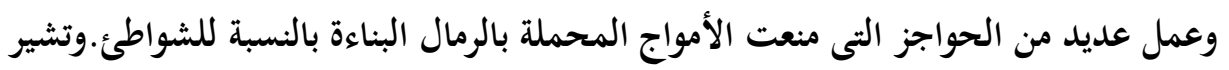

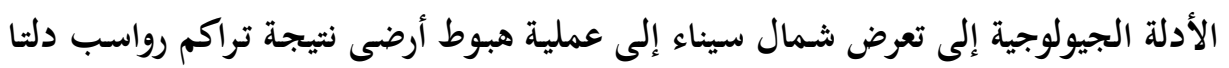

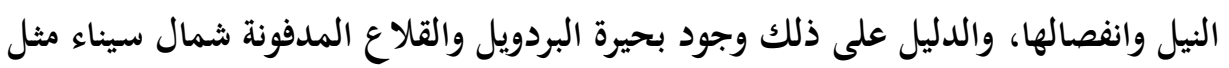
قلعة العريش وقلعة لحفن وطريق المحمل المقدس وطريق حورس، وهذه شواهد تشير إلى لى

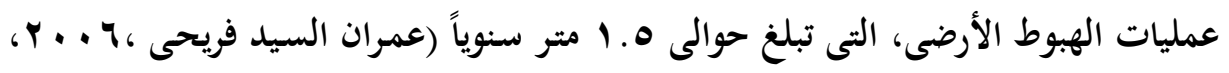
. 
كمـا أسفرت القياسـات الميدانيـة وتحليل ومعالجـة المرئيـات الفضـائية لفترات زمنيـة

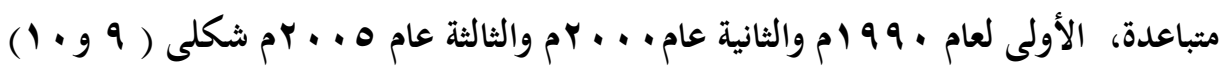
وجود تباين ملحوظ فى معدلات النحت والترسيب على امتداد شواطئ منطقة الدراسة، وإن

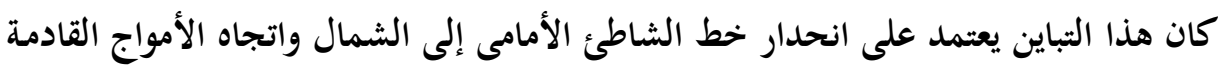

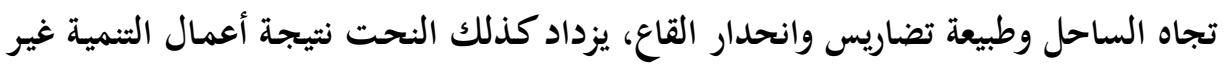
المخطط لها كما هى الحال شرق ميناء العريش، حيث قامت الشركة المسئولة عن الميناء

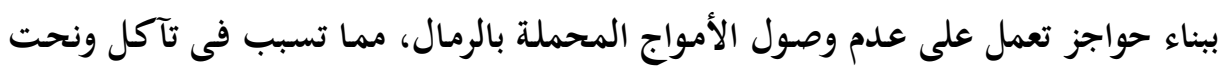

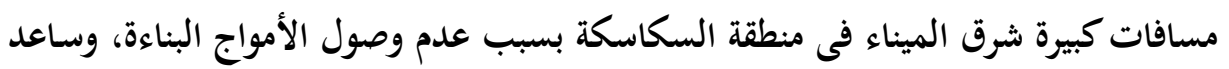
ذلك على زيادة عمق المياه الملاصقة له والتى بلغت بمد، كما هو الحال فى منطقة النخيل،

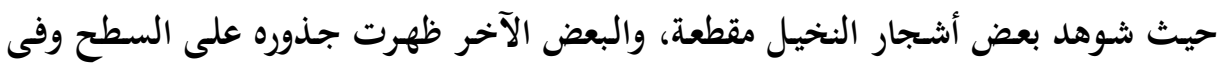
طريقه إلى الاقتلاع صورة (• (1) حيث كان يتمتع شاطئ العريش بالاستقرار والهدوء، وأصبح

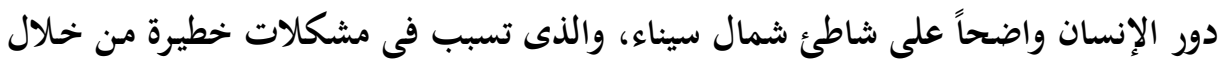

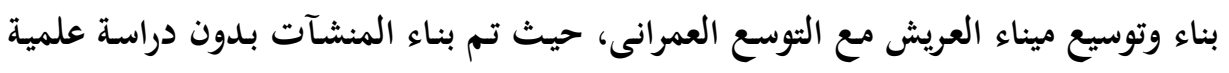

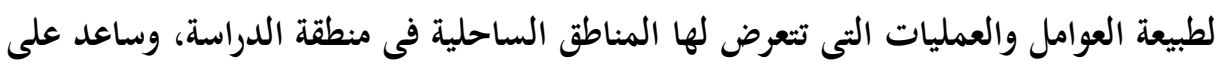

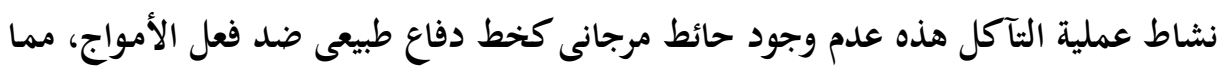
جعلها فريسة سهلة.

وتبعاً لذلك يمكن تقسيم شاطئ منطقة الدراسة إلى أربعة قطاعات (شكل (1) منها

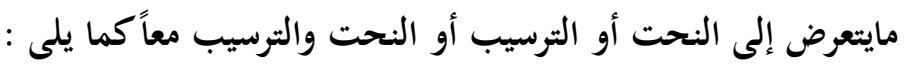




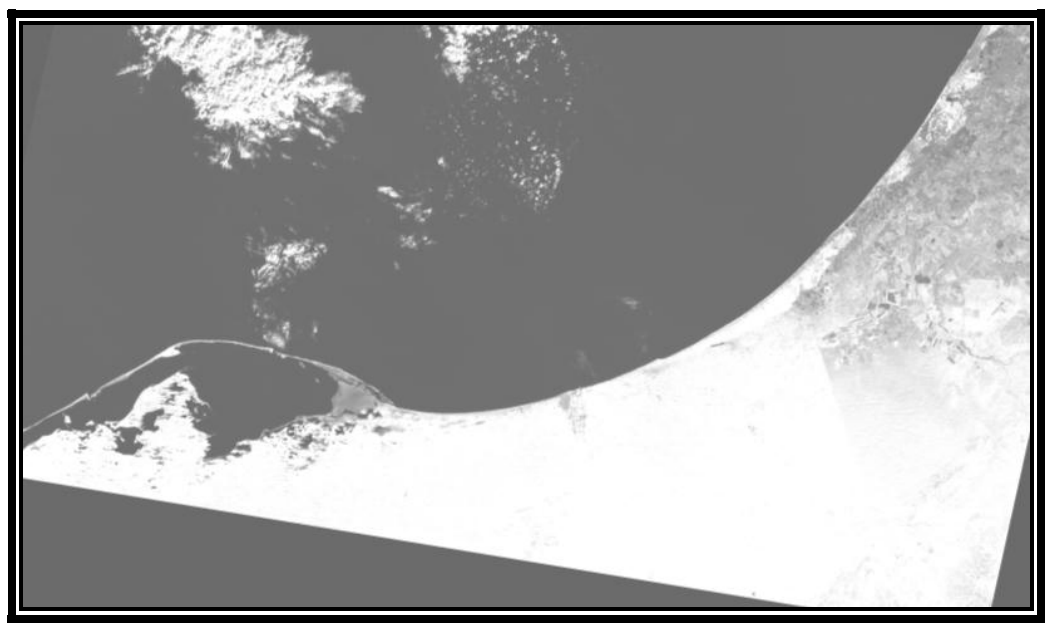

شكل (9 ) مرئية فضائي لمنطقة الدراسة عام • 99 | م

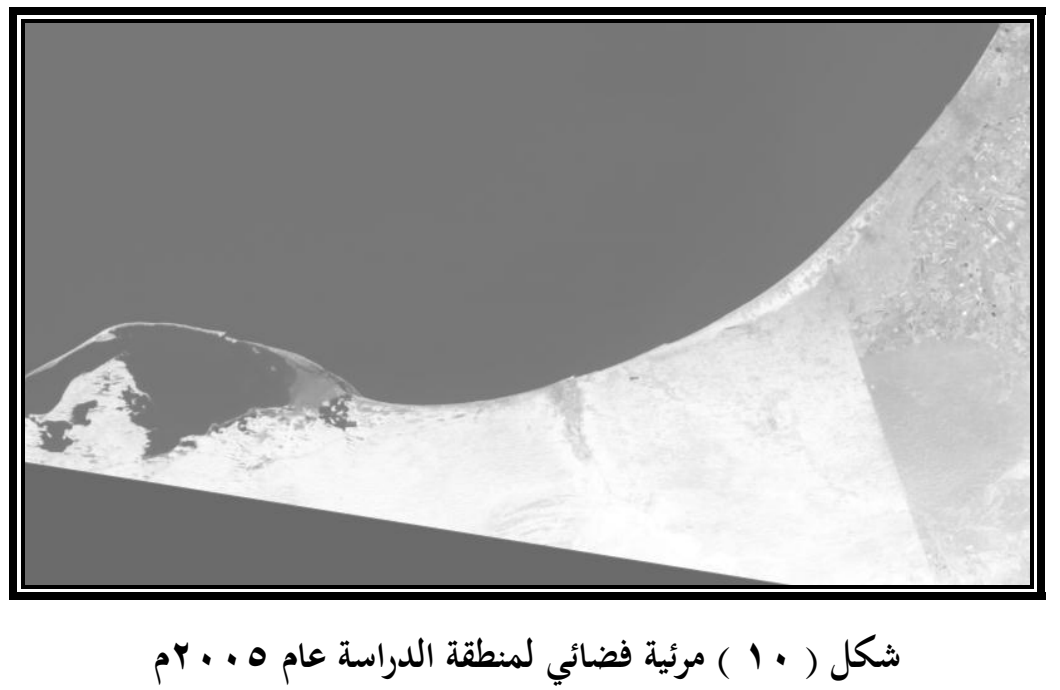




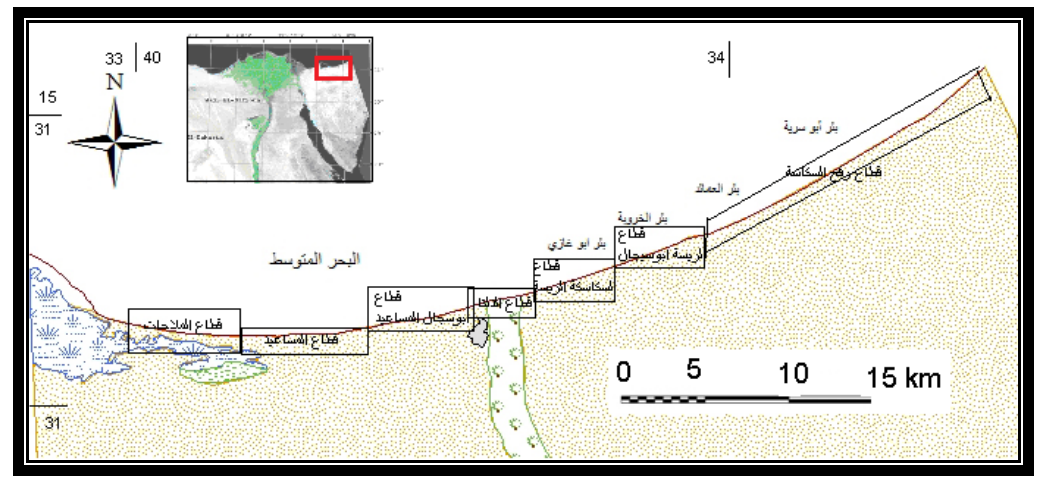

شكل (11) مواقع قطاعات النحت والترسيب

$$
\text { 1. قطاع السكاسكة - الريسة شرق ميناء العريش. }
$$

يتميز هذا القطاع بزيادة معدلات النحت بشكل واضح خاصة بعد بناء حاجز الأمواج

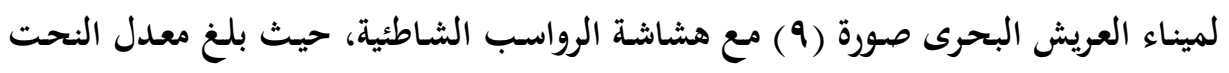

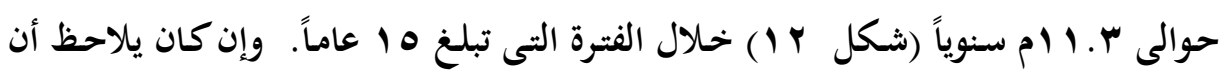

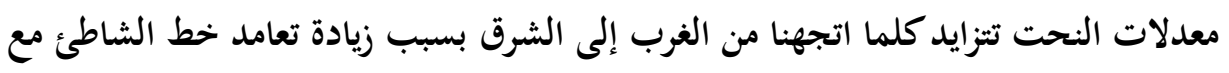

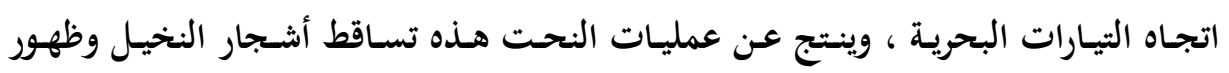

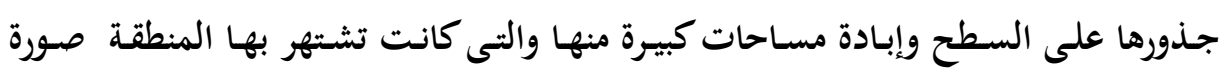

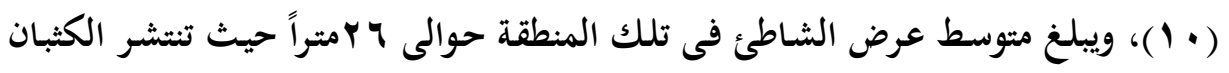

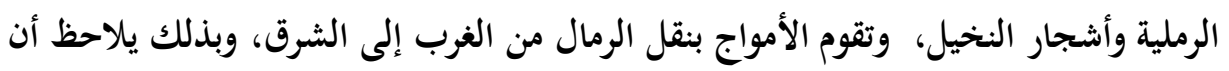

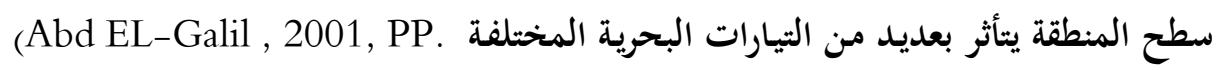

$$
.265-266)
$$




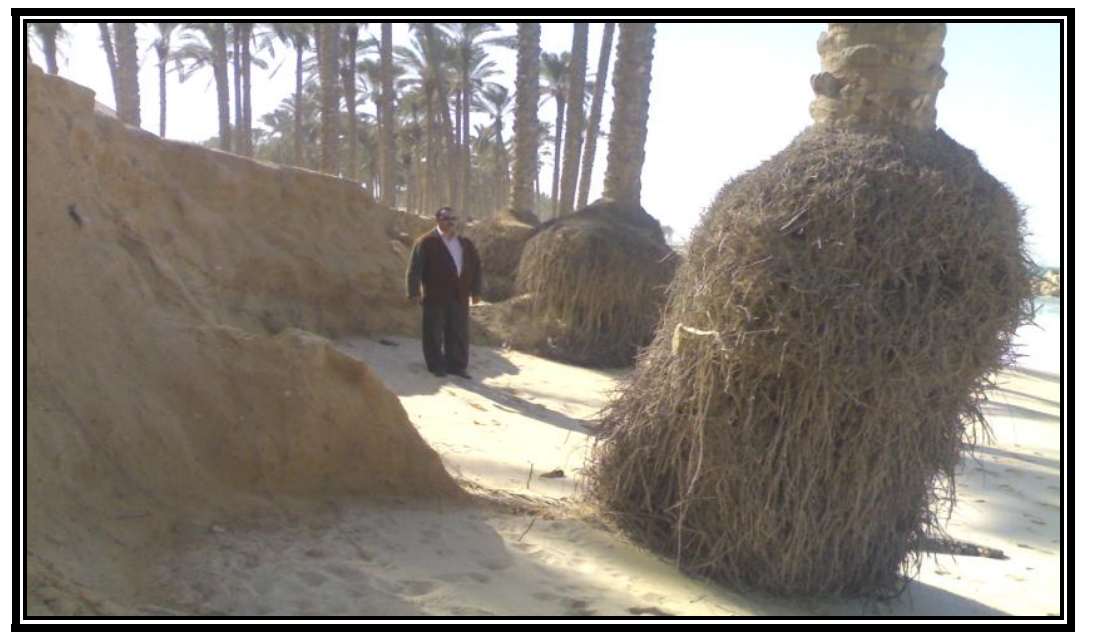

صورة (• 1) دور الأمواج فى نحت الشاطئ واقتلاع أشجار النخيل من جذورها

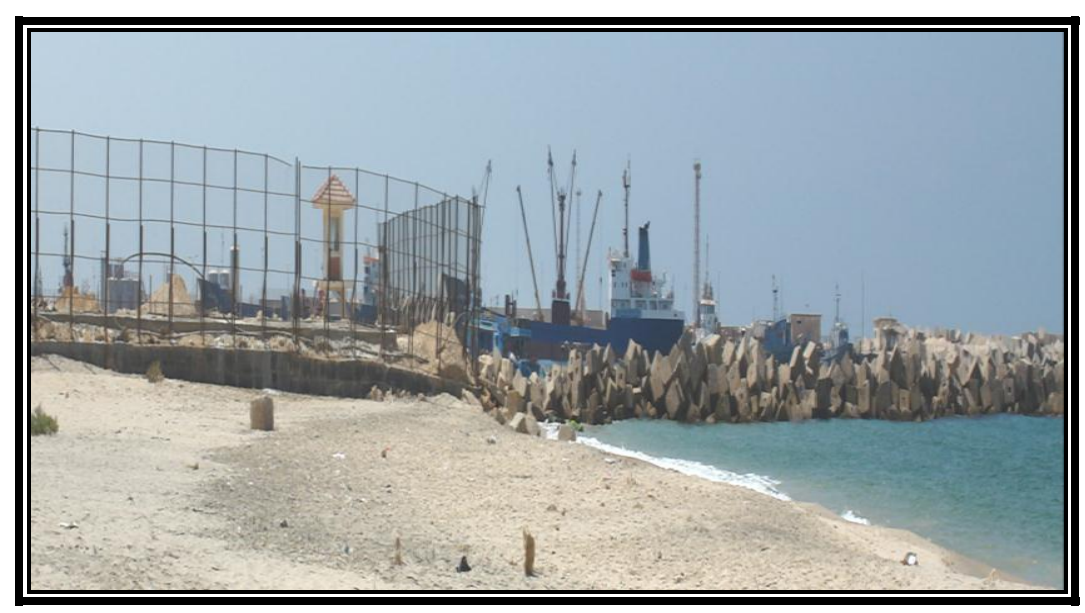

صورة (1 1) حاجز الأمواج لميناء العريش 


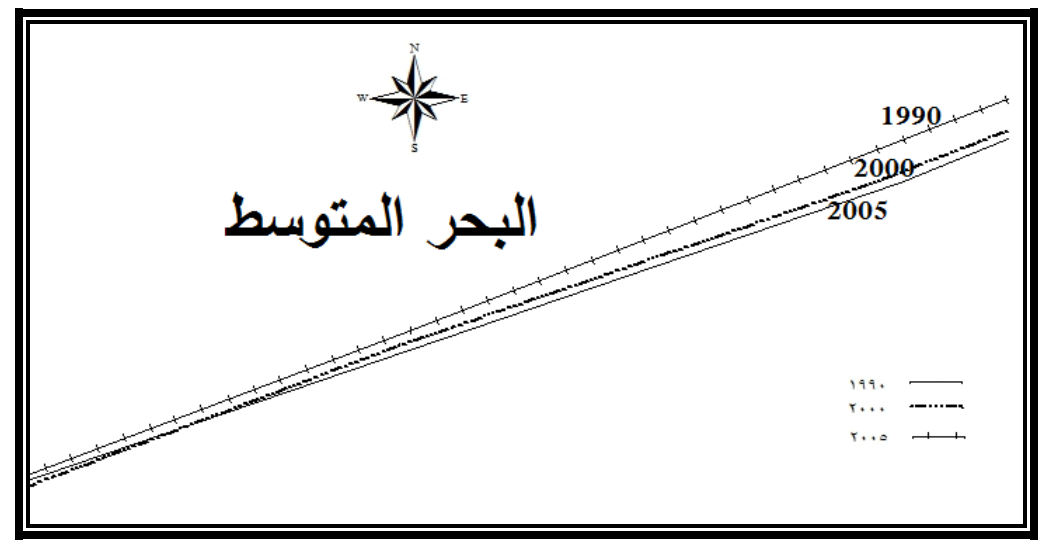

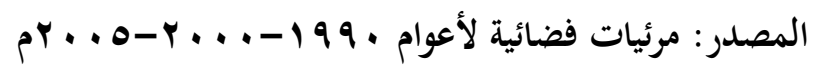

شكل( Y Y ) تأكل ونحت الثاطئ فى قطاع السكاسكة كما توضحه المرئيات الفضائية لأعوام مختلفة

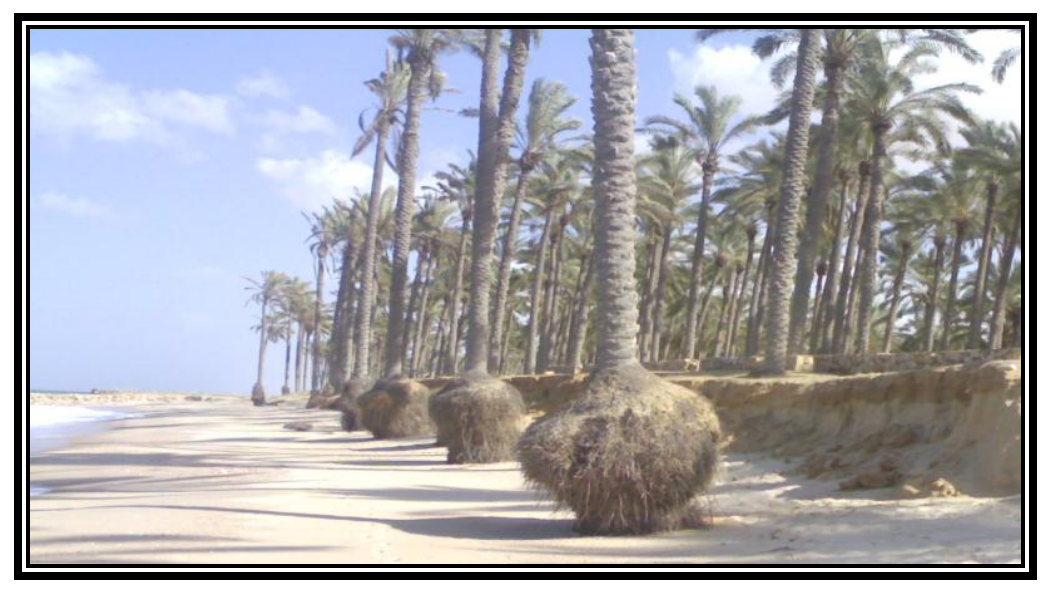

صورة (Y I ) تدمير أشجار النخيل بمنطقة الدراسة

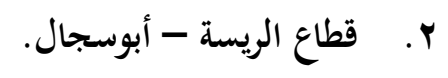

يتراجع الشاطئ فى هذا القطاع وإن كانت بنسب أقل من القطاع السابق لتبلغ حوالى ^. ع م سنوياً، وذلك بسبب تعامد حاجز الأمواج على خط الشاطئ، مما يساعد على نشاط

$$
\text { تأثير التيارات البحرية فى عمليات النحت (شكل با | ). }
$$




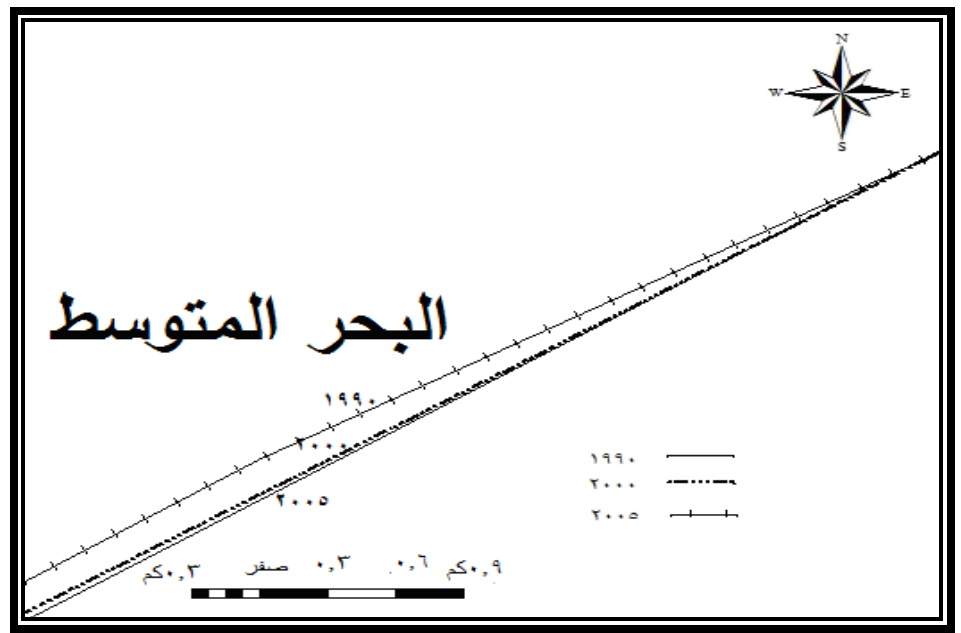

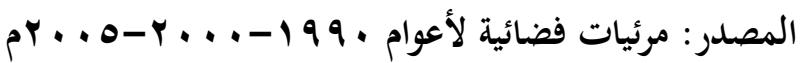

شكل (ب ا ( ) تأكل ونحت الشاطئ فى قطاع الريسة كما توضحه

المرئيات الفضائية لأعوام مختلفة

ץ. قطاع أبوسجال - المساعيد غرب مدينة العريش.

يبلـغ معـدل تأكـل الشـاطئ حوالى لا. ام/سـنوياً، مما ينتج عنسه تراجـع خط الشـاطئ

وتسـاقط أشـار النخيسل وتآكحل سـواحل بعض القـى السياحية مثل قريسة عثمـاثون وظلال

النخيل وكورنيش العريش.

ع. قطاع المساعيد - شرق محمية الزرانيق.

يزداد معـدل النحت والتآكل فى هذه القطاع عن القطاع السـابق حيث يبلغ حوالى ه. 7 م / سنوياً وذلك بسبب وجود حاجز أمواج محطة الكهرباء البخارية، الذى يؤثر على اتجاه التيارات البحريـة وزيـادة معدلات النحـت شـرق المحطة، مما كان له عظيم الأثر فى لي نحت وتآكل شاطئ قرية سما العريش السياحية واقتراب المسطح المائى بشكل واضح من الشـاليهات، للذلك عملت القريـة على تغذيـة الشـاطئ بالرمـال بصفة مستمرة Zaghloul) ., 1997, P.199) 
نخلص مس تحليـل المرئيسات الفضـائية ( باسـتخدام برنـامج Arc Gis ) والدراسـة الميدانية أن هناك تراجعاً واضحاً فى خط الشاطئ، وإن كان يختلف من من منطقة إلى أخرى، ويرجع ذلك إلى مجموعة من الأسباب أهمها:

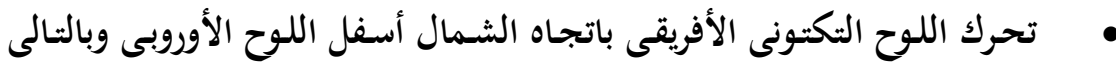

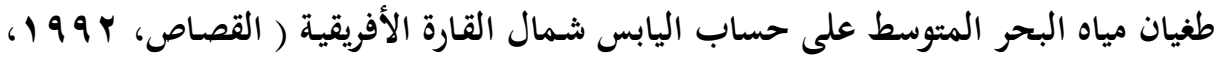
ص ارتفاع درجة حرارة الأرض وبالثالى ذوبان الجليد فى القطبين الشمالى والجنوبى مما يعقبه ارتفاع مستويات مياه البحار والمحيطات وطغيانها على اليابس.

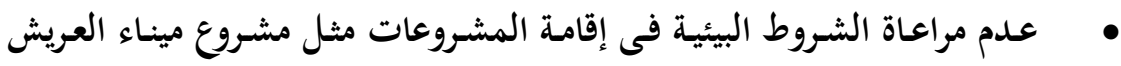

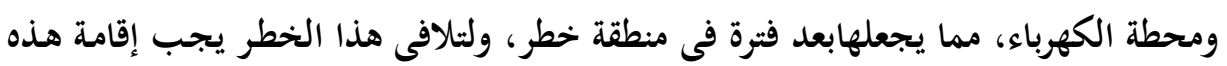
المشروعات على بعد لايقل عن · . ب متر من البحر.

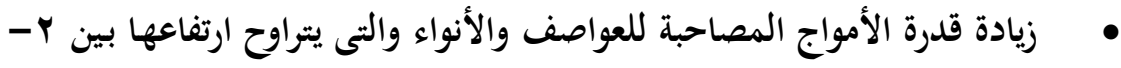

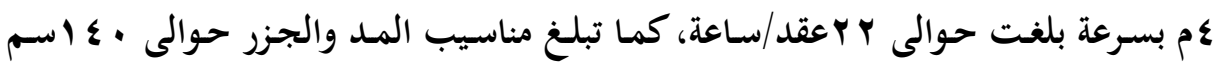

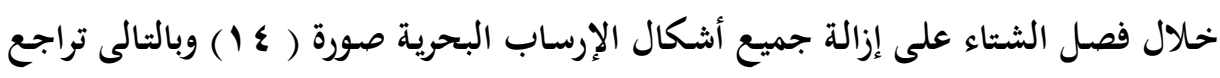
شاطئ منطقة الدراسة.

تسبب ميناء العريش ومحطة الكهرباء البخارية فى إحداث خلل واضح وزيادة

$$
\text { معدلات النحت إلى الشرق منها. }
$$

يتميز ساحل منطقة الدراسة بأنه يتعرض للنحت من جانب والترسيب فى جانب آخر،

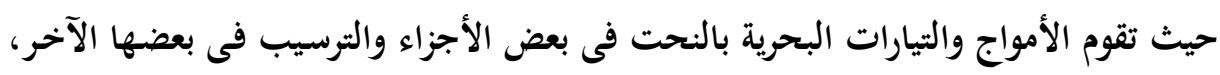
كما تختلف عمليات الترسيب بشكل واضح من منطقة إلى أخرى كما يلى: 


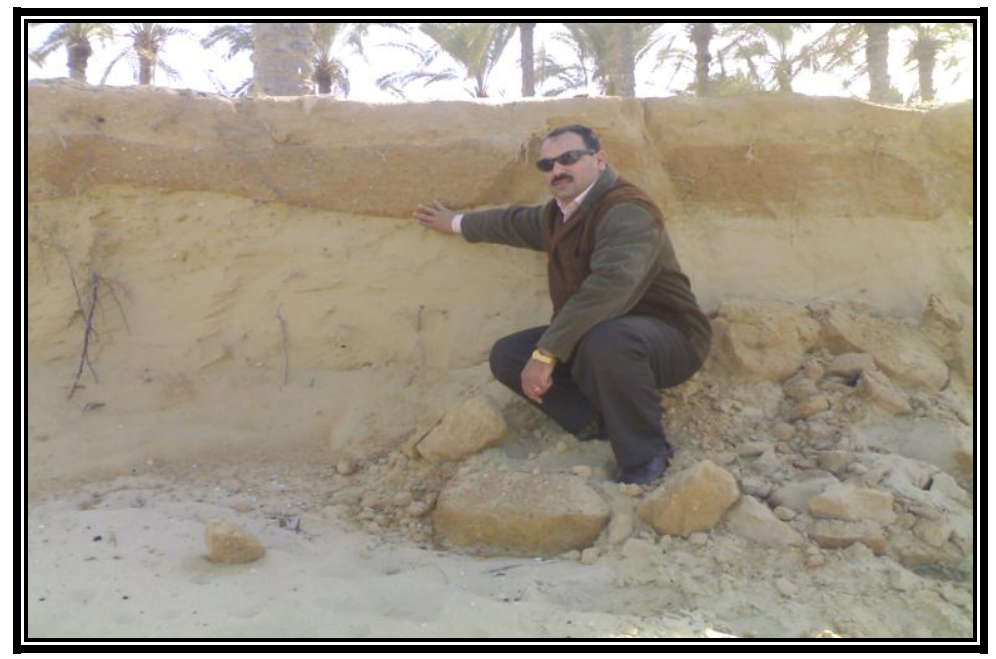

صورة (W I ) دور الأمواج فى نحت وإزالة نواتج الإرساب البحرى

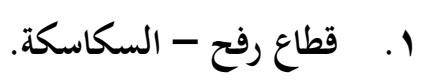

يتعرض هذا القطاع لعمليات الترسيب بمعدل يبلغ I ـآم سنوياً، وذلك بسبب قيام الأمواج الثـمالية الغربيـة المحملـة بالرمال بالاصسطدام بالشـاطئ، الـذى ينثنى إلى الثـمال

$$
\text { والشمال الثرقى. }
$$

Y. . ططاع ممتد من حاجز ميناء العريش حتى دلتا وادى العريش.

يعتبر من أكثر القطاعات التى تتعرض إلى عملية الترسيب خاصة فى المنطقة الواقعة غرب حاجز الأمواج البالغ طوله حوالى • •Vم. والذى ساعد على اصطدام التيارات البحرية 


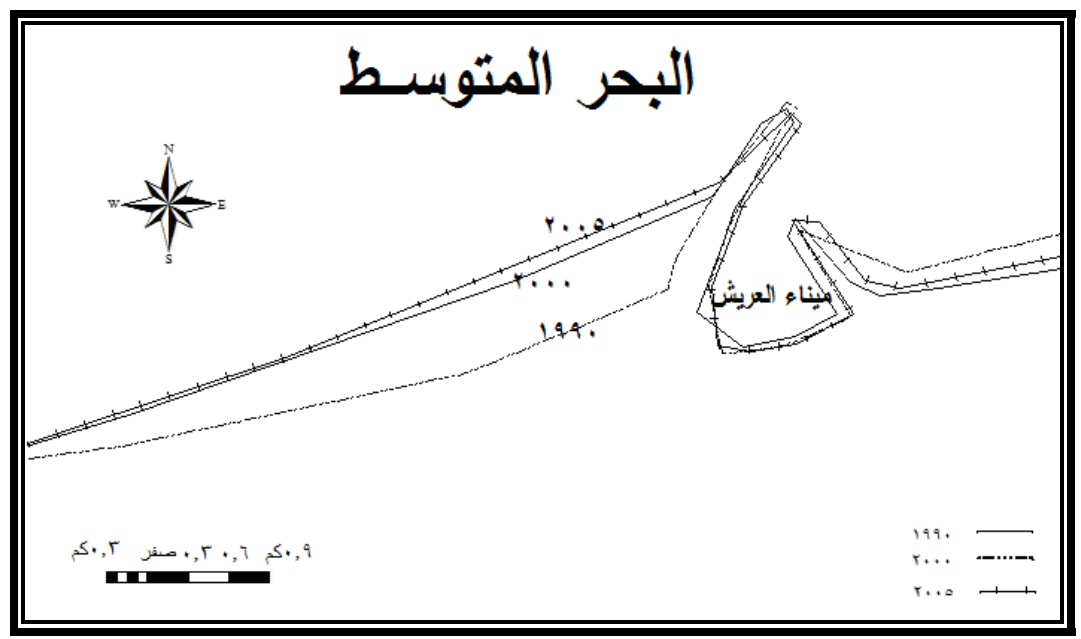

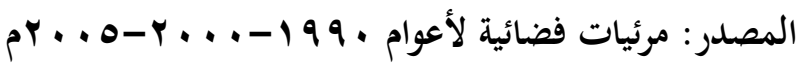

شكل( ع 1) الترسيب فى قطاع حاجز ميناء العريش كما تظهره

\section{المرئيات الفضائية لأعوام مختلفة}

والأمواج الشمالية الغربية المحملة بالرمال فيلقى هذه الحمولة غرب الميناء وإطماء

مسـاحات مـ البحر عامـاً بعـد الآخر، حيـث يبلغ مقـدار تقـدم اليابس على حسـاب البحر حوالى 1 ـ 1 ( م سنوياً ( شكل ع 1)، وتسبب عمليات الترسيب المستمرة بهذه المنطقة على قاع ميناء العريش خطراً مباشراً على السفن والمراكب.

ب. قطاع ممتد من المساعيد حتى ملاحات شركة النصر للملاحات شرق بحيرة

البردويل.

تزداد معـلات الترسيب على طول امتداد هـذا القطاع، والذى يبلغ حوالى ع ــ م

سنوياً، وإن كان معدل الترسيب يزداد كلما اتجهنا إلى الغرب ليبلغ حوالى ع ب م سنوياً شمال بحيرة البردويل، وترجع زيادة معدلات الترسيب إلى فروع نهر النيل القديمة والحديثة، وما تلقيه مـن رواسـب فى ميـاه البحر المتوسط ثم قيـام التيارات البحرية بتحريكها على امتـداد الساحل الشمالى الغربى لشبه جزيرة سيناء (شكل • 


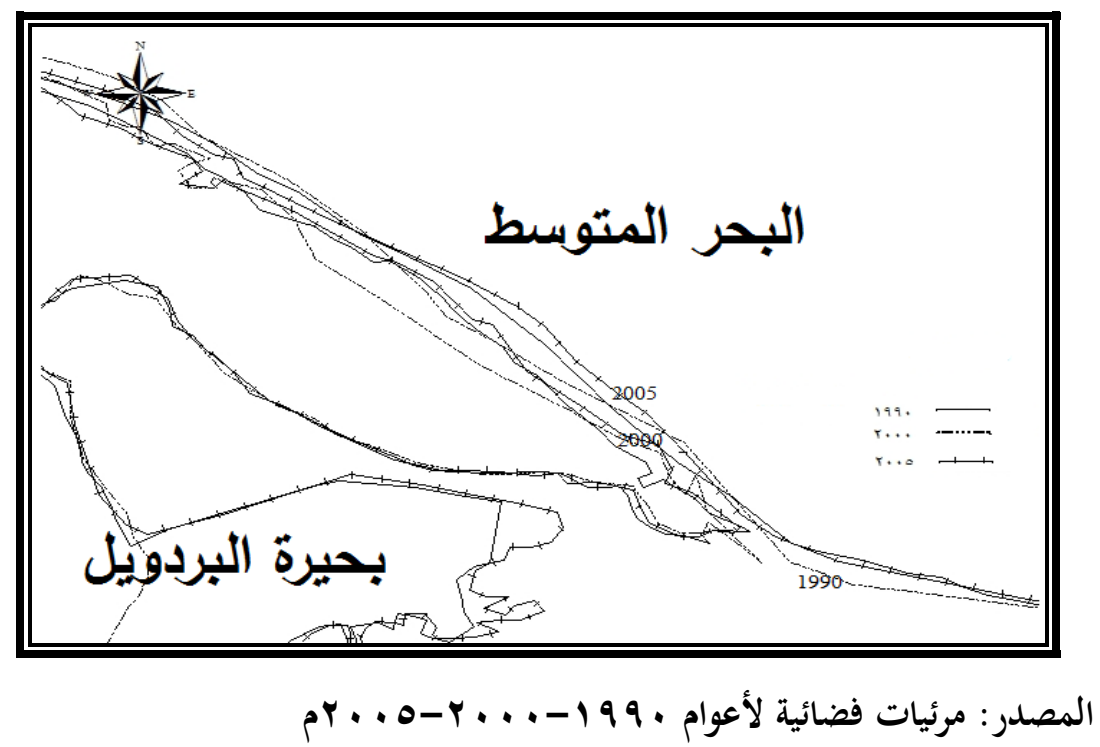

شكل( 1 ) الترسيب فى قطاع حاجز شرق بحيرة البردويل كما توضحه المرئيات الفضائية لأعوام مختلفة 


\section{الخحلاصة}

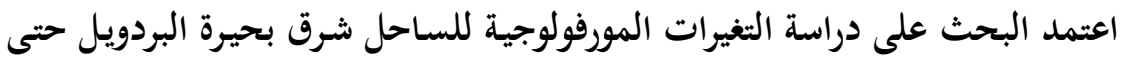
الحدود المصرية الفلسطينية، حيث تتعوض المنطقة إلى العديد من الأخطار الطبيعية، أهمها

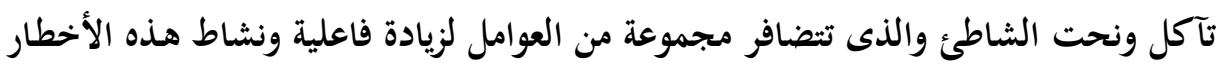

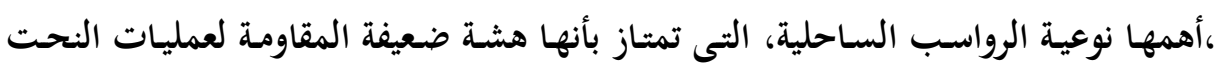

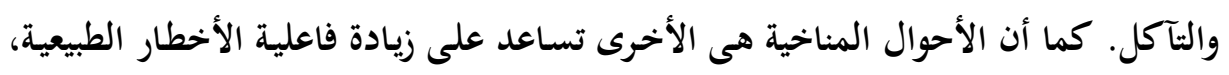

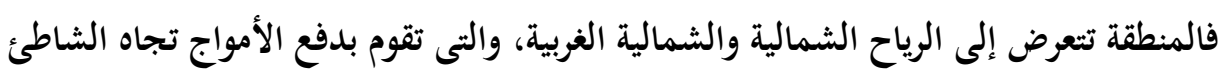

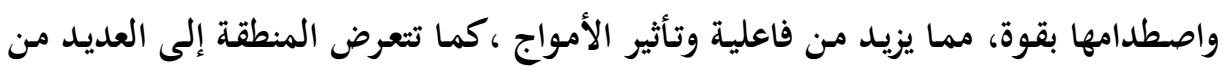

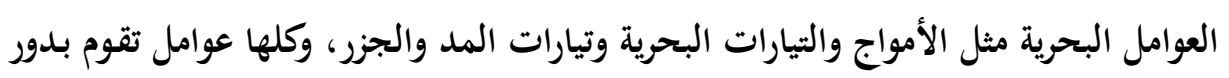

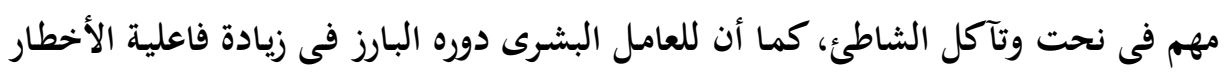

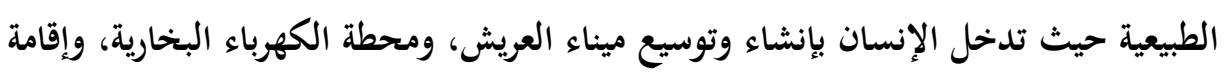

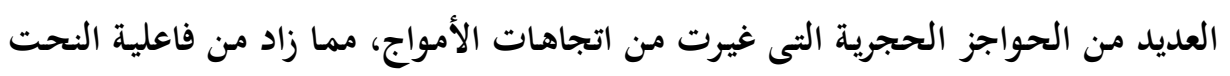

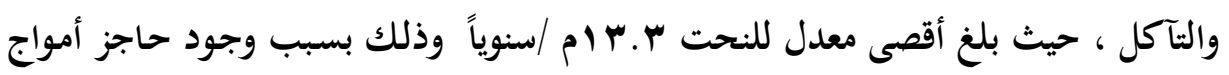

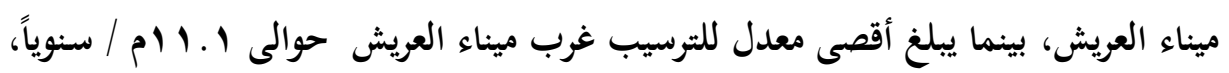

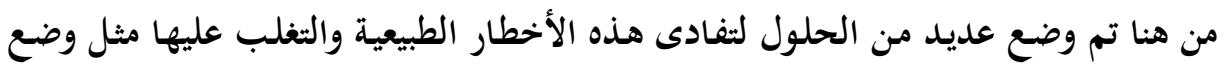

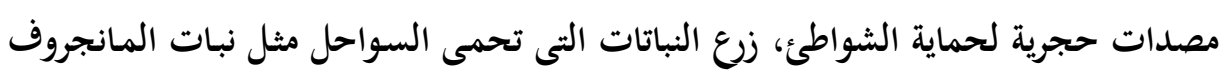
فى مناطق النحت. 


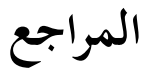

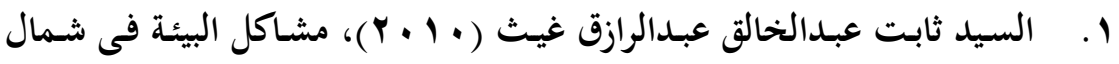

سيناء والخيارات البديلة، دراسة تطبيقية فى جغرافية البيئة، رسالة دكتوراه غير منشورة، قسم الجغرافيا بكلية الآداب جامعة بنها.

Y. . أيملى محمد حلمى حمادة (919 (19) ، القحط الزراعى فى شمال سيناء، دراسة

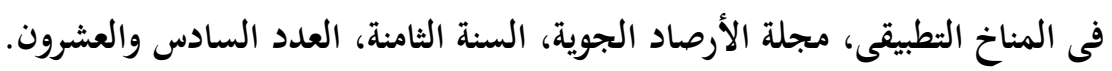

ب. على محمود القصاص ( ب99 (1)، ندوة نحر الشواطئ جريدة الأهرام، العدد

VIV

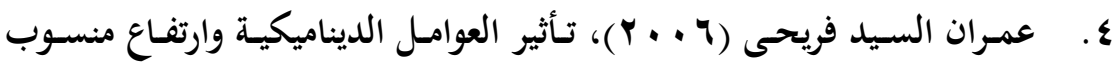

سطح البحر على شواطئ البحيرات الساحلية الشمالية بشمال مصر، مؤتمر شواطئ وبحيرات مصر الشمالية، قسم الجيولوجيا ، كلية العلوم، جامعة قناة السويس، الإسماعيلية.

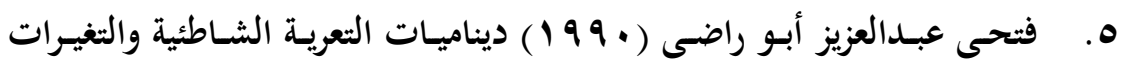

المعاصرة لساحل دلتا النيل، مجلة كلية الآداب، جامعة طنطا، العدد السادس.

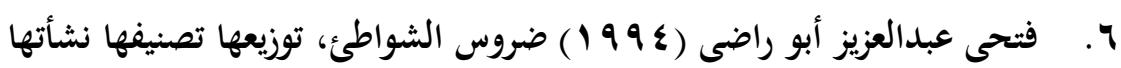

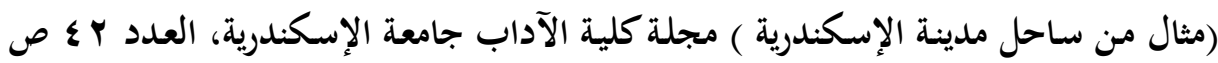

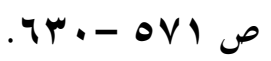

V. محمـد صسبرى محسـوب (91999)، العمليـات الجيومورفولوجيـة، دار الثقافـة للنشر والتوزيع، القاهرة.

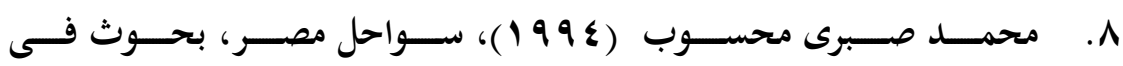
الجيومورفولوجيا، دار الثقافة للنشر والتوزيع، القاهرة. 


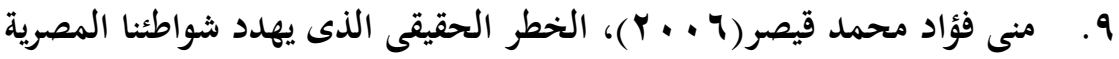
وكيفيـة مواجهته، مؤتمر شـواطئ وبحيرات مصر الشـمالية، قسم الجيولوجيا ، كليـة العلوم، جامعة قناة السويس، الإسماعيلية. المراجع الأجنبية

1. Abd El-Kader El-Sayed (2005) Beach Erosion and Accretion between the mouth of Rosetta branch and Kitchener drain outlet Nile Delta coast, Egypt bulletin of the Egyptian geographical society, Vol.78 tome LXX V11., pp27 -64.

2. Abou-Raddy ,F.A. (1989) Local Areal Variations of beach sand along the coast of Alexandria city, Egypt, Bull. Of the Faculty or Arts ,univ. of Alexandria VO1, XXX/ PP,35-67.

3. Ahmed M. Morsy, Omar A. Hegab and Mohamed I. Ismail (1995) Lithostratigraphy and sedimentology of the subsurface Quaternary in northeast Sinai, Egypt, Proc., 4 th Conf. Geol. Sinai Develop., Ismailia, pp. 141-158.

4. Bird ,E.C.F.,(1987) Coasts : An Introduction to Systematic Geomorphology, VOI. $4,4^{\text {th }}$ Ed the M.I.I. press, London.

5. Bruun, P.( 1962) Sea level rise as a cause of shore erosion', Proc. Am. Soc. Civ. Eng., J. Water Harbors Div. 88, 117-130.

6. Cheicoff, S. and Venkatakrishnan, R.(1995) : An introduction to physical geology worth publishers, New York, pp.593.

7. Cooke, R.U., Brunsden, D.,Doorankamp, J.C.and Jones, D.K.C., (1982) Urban geomorphology in Dry lands, the united nations univ., Oxford univ. press. 
8. El-Rakaiby.M.L. and Attia. N.a. , (2005) Morphological and Geological Classification of the Egyptian Northern Coastal Environment using space image Technology. Bulletin of the Egyptian Geographical society, Vol.78, Tome LXX Vll, PP. 91109.

9. Frihy, O.E. and Lotfy, M.F.( 1997) Shoreline changes and beach-sand sorting along the northern Sinai coast of Egypt', Geo-Marine Lett. 17, 140-146.

10. Ibrahim EL shamy . Klaus D.Balke and Mohamed H.Geriesh (1995) Modeling ground water Flow in the newly reclaimed areas of the Suez Canal province, Egypt. Proceedings of the Fourth conference Geology of Sinai For development. Ismailia, pp.171-188.

11. Mahmoud M. El Banna, Omran E. Frihy (2009) Humaninduced changes in the geomorphology of the northeastern coast of the Nile delta, Egypt Contents lists available at Science Direct Geomorphology journal homepage ,pp 72-78.

12. Abd El-Galil Mohamed (2001) Beach Erosion It is Relation With the Construction of El-Arish Harbor, Northern Sinai Geology of Sinai for Development Ismailia, pp. 263-272.

13. Nafaa ,M.G., Fanos, A.M. and Elganainy, M.A.,(1991) Characteristics of wave of the Mediterranean coast of Egypt . Journal of Coastal Research .Vol. 7,pp. 665-676. 